\title{
Caspase Functions in Cell Death and Disease
}

\author{
David R. Mcllwain ${ }^{1,2}$, Thorsten Berger ${ }^{1}$, and Tak W. Mak \\ The Campbell Family Institute for Breast Cancer Research and Ontario Cancer Institute, University \\ Health Network, Toronto, Ontario M5G 2C1, Canada \\ Correspondence: tmak@uhnres.utoronto.ca
}

Caspases are a family of endoproteases that provide critical links in cell regulatory networks controlling inflammation and cell death. The activation of these enzymes is tightly controlled by their production as inactive zymogens that gain catalytic activity following signaling events promoting their aggregation into dimers or macromolecular complexes. Activation of apoptotic caspases results in inactivation or activation of substrates, and the generation of a cascade of signaling events permitting the controlled demolition of cellular components. Activation of inflammatory caspases results in the production of active proinflammatory cytokines and the promotion of innate immune responses to various internal and external insults. Dysregulation of caspases underlies human diseases including cancer and inflammatory disorders, and major efforts to design better therapies for these diseases seek to understand how these enzymes work and how they can be controlled.

C aspases are a family of genes important for maintaining homeostasis through regulating cell death and inflammation. Here we will attempt to summarize what we currently know about how caspases normally work, and what happens when members of this diverse gene family fail to work correctly.

Caspases are endoproteases that hydrolyze peptide bonds in a reaction that depends on catalytic cysteine residues in the caspase active site and occurs only after certain aspartic acid residues in the substrate. Although caspase-mediated processing can result in substrate inactivation, it may also generate active signaling molecules that participate in ordered processes such as apoptosis and inflammation. Accord- ingly, caspases have been broadly classified by their known roles in apoptosis (caspase-3, -6, $-7,-8$, and -9 in mammals), and in inflammation (caspase-1, -4, -5, -12 in humans and caspase-1, -11, and -12 in mice) (Fig. 1). The functions of caspase-2, -10 , and -14 are less easily categorized. Caspases involved in apoptosis have been subclassified by their mechanism of action and are either initiator caspases (caspase8 and -9) or executioner caspases (caspase-3, -6, and -7$)$.

Caspases are initially produced as inactive monomeric procaspases that require dimerization and often cleavage for activation. Assembly into dimers is facilitated by various adapter proteins that bind to specific regions in

\footnotetext{
${ }^{1}$ These authors contributed equally to this work.

${ }^{2}$ Present address: Department of Gastroenterology, Hepatology and Infectious Diseases, University of Düsseldorf, 40225 Düsseldorf, Germany.

Editors: Eric H. Baehrecke, Douglas R. Green, Sally Kornbluth, and Guy S. Salvesen

Additional Perspectives on Cell Survival and Cell Death available at www.cshperspectives.org

Copyright (C) 2013 Cold Spring Harbor Laboratory Press; all rights reserved; doi: 10.1101/cshperspect.a008656

Cite this article as Cold Spring Harb Perspect Biol 2013;5:a008656
} 
D.R. Mcllwain et al.

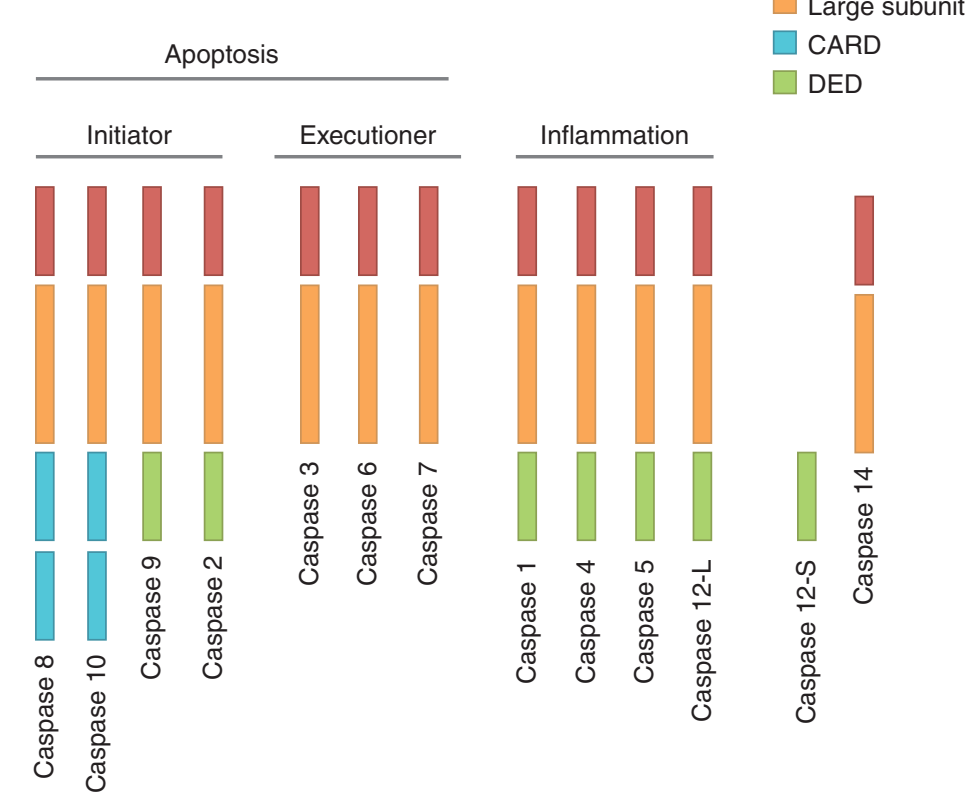

Figure 1. Domain structure of human caspases.

the prodomain of the procaspase. The exact mechanism of assembly depends on the specific adapter involved. Different caspases have different protein-protein interaction domains in their prodomains, allowing them to complex with different adapters. For example, caspase-1, $-2,-4,-5$, and -9 contain a caspase recruitment domain (CARD), whereas caspase- 8 and -10 have a death effector domain (DED) (Taylor et al. 2008).

\section{PHYSIOLOGICAL CASPASE FUNCTIONS}

\section{Caspases in Apoptosis}

Apoptosis is programmed cell death that involves the controlled dismantling of intracellular components while avoiding inflammation and damage to surrounding cells. Initiator caspases activate executioner caspases that subsequently coordinate their activities to demolish key structural proteins and activate other enzymes. The morphological hallmarks of apoptosis result, including DNA fragmentation and membrane blebbing.

\section{Initiator Caspases}

The initiator caspases- 8 and -9 normally exist as inactive procaspase monomers that are activated by dimerization and not by cleavage. This process is generalized as an "induced proximity model" (Muzio et al. 1998; Boatright et al. 2003; Chang et al. 2003), in which upstream signaling events induce caspase dimerization and activation. Dimerization also facilitates autocatalytic cleavage of caspase monomers into one large and one small subunit, which results in stabilization of the dimer.

\section{Executioner Caspases}

Inappropriate activation of the executioner caspases-3, -6 , and -7 is prevented by their production as inactive procaspase dimers that must be cleaved by initiator caspases. This cleavage between the large and small subunits allows a conformational change that brings the two active sites of the executioner caspase dimer together and creates a functional mature protease (Riedl and Shi 2004). Once activated, a single executioner caspase can cleave and activate 
other executioner caspases, leading to an accelerated feedback loop of caspase activation.

\section{Pathways of Apoptosis}

Various apoptotic pathways exist that can be distinguished by the adapters and initiator caspases involved. Most apoptotic programs fall into either the extrinsic or intrinsic category (Fig. 2).

The Extrinsic Pathway of Apoptosis. Extrinsic apoptosis is triggered by extracellular cues delivered in the form of ligands binding to death receptors (DRs). Death receptors are members of the tumor necrosis factor (TNF) superfamily and include TNF receptor-1 (TNFR1), CD95 (also called Fas and APO-1), death receptor 3
(DR3), TNF-related apoptosis-inducing ligand receptor-1 (TRAIL-R1; also called DR4), and TRAIL-R2 (also called DR5 in humans). Rodents have only one TRAIL-R protein and it resembles DR5. Death receptor ligands include TNF, CD95-ligand (CD95-L; also called Fas-L), TRAIL (also called Apo2-L), and TNF-like ligand 1A (TL1A). The binding of a DR ligand to a DR causes the monomeric procaspase- 8 protein to be recruited via its DED to the deathinducing signaling complex (DISC) formed at the cytoplasmic tail of the engaged DR that also includes the adapter protein FAS-associated death domain (FADD) or TNFR-associated death domain (TRADD). Recruitment of caspase- 8 monomers results in dimerization

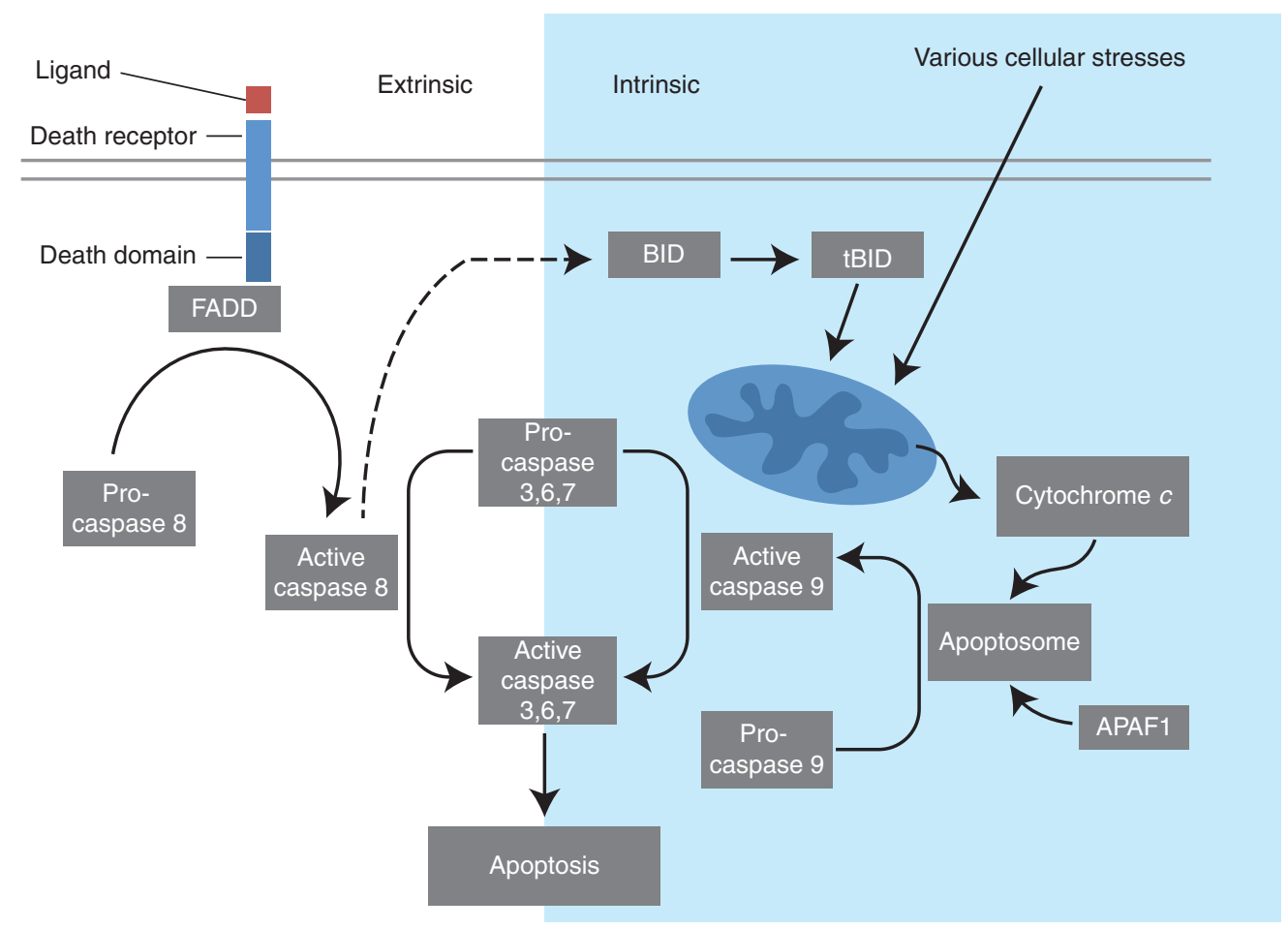

Figure 2. Extrinsic and intrinsic pathways of apoptosis. The extrinsic apoptosis pathway is activated through the binding of a ligand to a death receptor, which in turn leads, with the help of the adapter proteins (FADD/ TRADD), to recruitment, dimerization, and activation of caspase-8. Active caspase- 8 then either initiates apoptosis directly by cleaving and thereby activating executioner caspase $(-3,-6,-7)$, or activates the intrinsic apoptotic pathway through cleavage of BID to induce efficient cell death. The intrinsic or mitochondrial apoptosis pathway can be activated through various cellular stresses that lead to cytochrome $c$ release from the mitochondria and the formation of the apoptosome, comprised of APAF1, cytochrome $c$, ATP, and caspase9, resulting in the activation of caspase-9. Active caspase-9 then initiates apoptosis by cleaving and thereby activating executioner caspases. 
D.R. Mcllwain et al.

and activation. Cells from gene-targeted mice

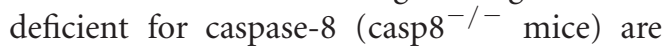
thus resistant to DR-induced apoptosis (Juo et al. 1998; Varfolomeev et al. 1998; Kang et al. 2004), as are cells from mutant mice lacking either FADD (Yeh et al. 1998) or TRADD, which are specifically defective for TNF- $\alpha$-mediated apoptosis (Chen et al. 2008b).

The outcome of DR-mediated activation of caspase-8 depends on the cell type. In so-called type I cells, caspase-8 initiates apoptosis directly by cleaving and thereby activating executioner caspases. In type II cells, caspase-8 must first activate the intrinsic apoptotic pathway (discussed below) to induce efficient cell death (Samraj et al. 2006). Type I and II cells differ in their content of intracellular inhibitor of apoptosis proteins (IAPs), which block executioner caspase function unless suppressed by proteins released from the mitochondria (Jost et al. 2009; Spencer et al. 2009).

The Intrinsic Pathway of Apoptosis. Intrinsic apoptosis is also known as mitochondrial apoptosis because it depends on factors released from the mitochondria. This pathway is activated by a vast array of cellular stresses, including growth factor deprivation, cytoskeletal disruption, DNA damage, accumulation of unfolded proteins, hypoxia, and many others. It can also be activated by developmental signals that instruct cells to die, such as hormones (Brenner and Mak 2009). The initiator caspase responsible for the intrinsic apoptosis pathway is caspase- 9 , which is activated by dimerization induced when the caspase-9 CARD domain binds to the adapter protein apoptotic protease-activating factor-1 (APAF1) (Shiozaki et al. 2002).

Both APAF1 and caspase-9 exist in a resting cell as cytosolic, inactive monomers. A cell experiencing stress first releases cytochrome $c$ from the mitochondria. The binding of cytochrome $c$ to the WD domain of the APAF1 monomer leads to a conformational change that exposes a nucleotide-binding site in the nucleotidebinding and oligomerization (NACHT) domain of APAF1. The nucleotide deoxy-ATP (dATP) binds to this site and induces a second conformational change in APAF1 that exposes both its oligomerization and CARD domains. Seven such activated APAF1 monomers then assemble into an oligomeric complex, the center of which contains the CARDs that recruit and activate caspase-9 (Acehan et al. 2002). The complex containing cytochrome $c$, APAF1, and caspase- 9 has been termed the apoptosome (Cain et al. 2002).

Cytochrome $c$ has a long established role in electron transport, and it was shown in 2000 that mammalian cells lacking cytochrome $c$ could not activate caspases in response to mitochondrial pathway stimulation (Yeh et al. 2000). However, it was not until 2005 that Hao et al. (2005) formally established that the electron transport function of cytochrome $c$ is independent of its ability to engage APAF1 and induce apoptosome formation and caspase activation. Cells from a knockin mouse mutant in which cytochrome $c$ was mutated at lysine 72, a key residue for APAF1 interaction, were able to carry out electron transport but not apoptosis (Hao et al. 2005).

The critical role of intrinsic apoptosis in mammalian development is illustrated by the phenotypes of gene-targeted mice deficient for components of this pathway (Table 1). During the development of the normal brain, apoptosis is critical for culling massive amounts of brain cells to allow selection of those making the best neural connections (Madden and Cotter 2008). Caspase-9-deficient mice suffer from large brain outgrowths characterized by decreased apoptosis and excessive neurons (Hakem et al. 1998; Kuida et al. 1998), as do casp3 $3^{-1-}$ mice (Kuida et al. 1996; Woo et al. 1998). In vitro, embryonic stem cells and embryonic fibroblasts derived from casp $9^{-/-}$mice are resistant to several intrinsic apoptotic stimuli, including UV and $\gamma$ irradiation. Apaf1 ${ }^{-1-}$ mice show a similar phenotype including reduced brain cell apoptosis, as well as striking craniofacial abnormalities associated with neuronal cell hyperproliferation. Apaf1 ${ }^{-/-}$cells cannot activate caspases in response to mitochondrial pathway stimulation, are resistant to many apoptotic stimuli, and display reduced processing of caspases-2, -3, and -8 (Yoshida et al. 1998).

Dual Role of Caspase-8 in Apoptosis and Necrosis. As mentioned earlier, caspase-8 plays an 
Caspase Functions in Cell Death and Disease

Table 1. Summary of caspase-deficient mouse phenotypes

Function derived

from deficient phenotype

References

\begin{tabular}{lc}
\hline Caspase & Mouse \\
Caspase-1 & $\begin{array}{c}\text { Develop normally; have no } \\
\text { defects in apoptosis }\end{array}$ \\
& \\
& \\
& \\
& \\
& \\
Caspase-2 & Develop normally and are \\
& fertile; have only minor \\
& apoptotic defects in \\
& some cell types; MEFs \\
& show resistance to killing \\
by HS and specific drugs
\end{tabular}
revealed functions in T-cell homeostasis,

\section{Caspase-9 Perinatal lethal, but not $100 \%$ penetrant}

Caspase-10 No mouse homolog

Caspase-11 Develop normally and are fertile
Are more susceptible to virus infection
(Thomas et al. 2009); show enhanced tumor formation (Hu et al. 2010);

have reduced apoptosis in several models such as neuronal cell death, myocardiac infarct, and heart failure (Frantz et al. 2003; Arai et al. 2006; Merkle et al. 2007); caspase-1-deficient mice are protected against cisplatininduced apoptosis and acute tubular necrosis (Faubel et al. 2004)

Caspase- 2 has been proposed to be involved in different proapoptotic pathways, but the data from the genedeficient mice do not support the majority of the in vitro results

Essential for neuronal cell death; caspase- 3 is an essential component in some apoptosis pathways, dependent on the stimulus and cell type; essential for the regulation of $\mathrm{B}$-cell homeostasis No apoptotic defects

No apoptotic defects

Cells from caspase-8-deficient mice are resistant to death-receptor-induced apoptosis; inactivating mutation in humans shows immunodeficiency; tissue-specific deletion of caspase- 8 in the generation of myeloid and lymphoid cells and the differentiation into macrophages, and in skin inflammation and wound healing; suppresses RIPK3-dependent necrosis

Kuida et al. 1995; Li et al. 1995; Thomas et al. 2009; Hu et al. 2010

Bergeron et al. 1998; O'Reilly et al. 2002; Tu et al. 2006

Kuida et al. 1996; Woo et al. 1998, 2003

Unpublished (see Zheng et al. 1999)

Lakhani et al. 2006

Juo et al. 1998; Varfolomeev et al. 1998; Chun et al. 2002; Salmena et al. 2003; Kang et al. 2004; Beisner et al. 2005; Kovalenko et al. 2009; Lee et al. 2009a; Li et al. 2010; Kaiser et al. 2011; Oberst et al. 2011; Zhang et al. 2011

Brain hyperplasia caused by decreased apoptosis and excess neurons; cells from caspase-9-deficient mice show resistance to apoptosis induced by a variety of cytotoxic drugs and irradiation

Human inactivating mutations are associated with ALPS II

Mutant mice are resistant to endotoxic shock induced by LPS; IL-1 production after LPS stimulation is blocked; is necessary for caspase-1 activation; regulates cell migration in lymphocytes
Hakem et al. 1998;

Kuida et al. 1998

Wang et al. 1999

Wang et al. 1998; Li et al. 2007 
D.R. Mcllwain et al.

Table 1. Continued

\begin{tabular}{|c|c|c|c|}
\hline Caspase & $\begin{array}{c}\text { Mouse } \\
\text { mutant phenotype }\end{array}$ & $\begin{array}{c}\text { Function derived } \\
\text { from deficient phenotype }\end{array}$ & References \\
\hline Caspase-12 & Develop normally & $\begin{array}{l}\text { Mice are resistant to ER stress-induced } \\
\text { apoptosis, but their cells undergo } \\
\text { apoptosis in response to other death } \\
\text { stimuli; thus, caspase-12 mediates an } \\
\text { ER-specific apoptosis pathway; show } \\
\text { an enhanced bacterial clearance and } \\
\text { are more resistant to sepsis }\end{array}$ & $\begin{array}{l}\text { Nakagawa et al. 2000; } \\
\text { Saleh et al. } 2006\end{array}$ \\
\hline Caspase-14 & $\begin{array}{l}\text { Develop normally and are } \\
\text { fertile; their long-term } \\
\text { survival was } \\
\text { indistinguishable from } \\
\text { that of wild-type mice }\end{array}$ & $\begin{array}{l}\text { Mice show increased sensitivity to UVB } \\
\text { irradiation; caspase-14-deficient } \\
\text { epidermal cells show no defect in } \\
\text { apoptosis; caspase-14 is responsible for } \\
\text { the correct processing of (pro)filaggrin } \\
\text { during cornification }\end{array}$ & Denecker et al. 2007 \\
\hline
\end{tabular}

MEF, mouse embryonic fibroblast; HS heat shock; ALPS, autoimmune lymphoproliferative syndrome; LPS, lipopolysaccharide; ER, endoplasmic reticulum; RIPK3, receptor-interacting serine/threonine-protein kinase 3.

important role in extrinsic apoptosis, combining with FADD to form the DISC. Interestingly, the deletion in mice of caspase-8, FADD, or the DISC regulatory protein FLICE-like inhibitory protein (FLIP) leads to embryonic death caused by a variety of defects. Some of these defects appear to be related to apoptosis, such as impaired heart muscle development in the absence of caspase-8 (Varfolomeev et al. 1998), cardiac failure in the absence of FADD (Yeh et al. 1998; Zhang et al. 1998), and disrupted heart development in the absence of FLIP (Yeh et al. 2000). However, tissue-specific deletions of caspase- 8 have revealed new roles for this caspase, which appear to be unrelated to apoptosis. Caspase- 8 function is also critical for T-cell homeostasis (Salmena et al. 2003), the generation of myeloid and lymphoid cells and macrophage differentiation (Kang et al. 2004; Beisner et al. 2005), and skin inflammation and wound healing (Kovalenko et al. 2009; Lee et al. 2009a; Li et al. 2010). Recently, three reports provided evidence that some of the defects associated with loss of caspase-8, and result in embryonic death, are not owing to impaired apoptosis but rather to defective suppression of receptor-interacting serinethreonine kinase 3 (RIPK3) -dependent necrosis (Kaiser et al. 2011; Oberst et al. 2011; Zhang et al. 2011). Thus, caspase- 8 appears to have dual roles in activation of apoptosis and suppression of necrosis, and caspase-8-dependent suppression of necrosis, but not caspase-8 activation of apoptosis, is critical for mouse embryonic survival.

\section{Caspases in Inflammation \\ Inflammatory Caspases}

Several caspases function as critical mediators of innate immune responses rather than proapoptotic factors. Caspase- $1,-4,-5$, and -12 comprise the inflammatory subset in humans, whereas caspase- $1,-11$, and -12 serve the same function in mice. Interestingly, the genes encoding inflammatory caspases are located in close proximity on human chromosome 11 and murine chromosome 9, suggesting that they may have arisen from gene duplication events. At the protein level, inflammatory caspases, like their proapoptotic counterparts, are produced as inactive procaspases in resting cells. Only after cellular stimulation via engagement of patternrecognition receptors (see below) are inflammatory caspases activated through the formation of a cytosolic complex termed the inflammasome (Martinon et al. 2002).

\section{Inflammasome Formation}

Inflammasome formation resembles apoptosome formation and has been best studied for 
the nucleotide-binding domain, leucine-rich repeat-containing (NLR) proteins, which are a family of pattern-recognition receptors (PRRs), and other proteins (Fig. 3). In a resting cell, NLR monomers are held in an inactive conformation until an external or internal stimulus promotes their assembly (similar to the assembly of APAF1 monomers in the apoptosome). NLR monomers interact through their NACHT domains and bind to the adapter protein apoptosis-associated speck-like protein containing a CARD (ASC/PYCARD) (Ting et al. 2008b). The presence of ASC permits the recruitment of an inactive inflammatory procaspase, typically procaspase-1, to the inflammasome, followed by cleavage and activation of caspase- 1 through induced proximity autocatalysis (Davis et al. 2011). Activated caspase- 1 in turn cleaves pro-IL-1 $\beta$ and pro-IL-18, which facilitates the secretion of these proinflammatory cytokines (Ting et al. 2008b).

Different NLR-driven inflammasomes contain different NLR members and respond to different stimuli, so that inflammasome formation and the resulting immune response are appropriately tailored to the specific context. However, precisely how inflammasomes are activated in various situations remains poorly understood. It is known that signals initiating inflammasome formation can be delivered by environmental irritants, pathogen-derived molecules, self-derived molecules associated with cell damage, or inappropriate metabolite accumulation (Davis et al. 2011). Whether these signals are received directly by NLR proteins or relayed through secondary pattern-recognition receptors remains unclear and is likely to be context dependent (Monie et al. 2009).

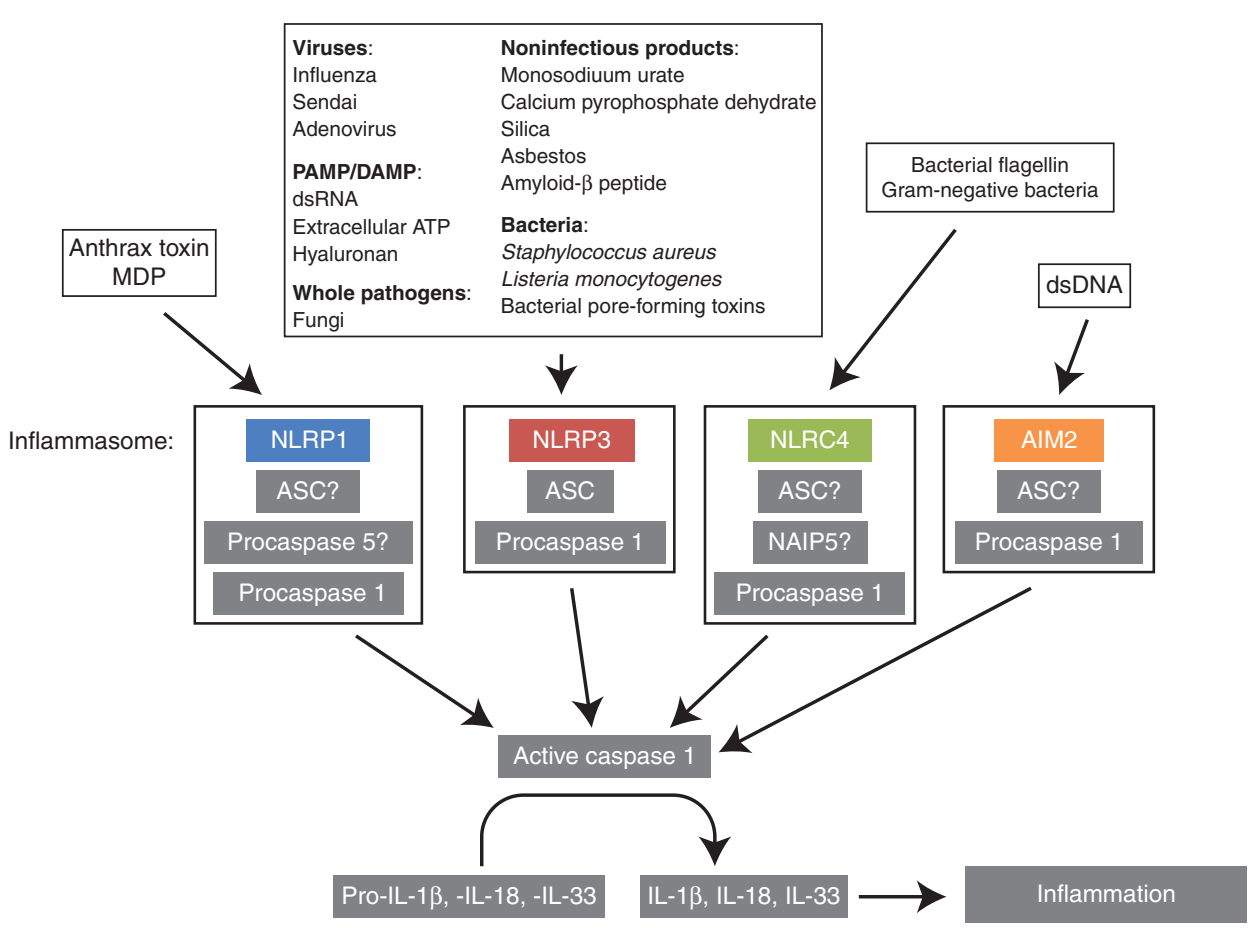

Figure 3. Signaling and composition of inflammasomes. Activation of inflammatory caspases such as caspase-1 is achieved through inflammasome formation. A multitude of cellular stimuli are recognized by a family of pattern-recognition receptors, engagement of which leads to the binding of the adapter protein ASC and the recruitment and activation of the inactive inflammatory procaspase, typically procaspase- 1 . Activated caspase- 1 in turn cleaves pro-IL-1 $\beta$, pro-IL-18, and pro-IL-33, which facilitates the secretion of these proinflammatory cytokines leading to inflammation. 
D.R. Mcllwain et al.

Role of Pattern-Recognition Receptors. PRRs are molecules that can detect pathogen-associated molecular patterns (PAMPs) or damageassociated molecular patterns (DAMPs) and initiate inflammasome formation. PRRs are frequently expressed by cells that make contact with invading microbes, such as epithelial cells and cells of the innate and adaptive immune responses. Several different classes of PRRs exist, including Toll-like receptors (TLRs) that recognize a variety of PAMPs derived from bacteria, viruses, and fungi and work in synergy with the cytosolic, C-type lectin receptors (CLRs) (which sense fungi), retinoic acid-inducible gene (RIG)-I-like receptors (RLRs) (which sense viruses), and NLR proteins (which sense bacteria) (Davis et al. 2011) (for recent reviews on CLRs and RLRs see Loo and Gale 2011; Osorio and Reis 2011).

TLRs. TLRs were originally named for their similarity to the Drosophila protein Toll (Anderson et al. 1985a,b) and were first described in 1997 (Medzhitov et al. 1997). Different TLRs recognize different bacterial components, including lipopolysaccharides (LPS), flagellin, lipoproteins, double-stranded viral RNA, and the unmethylated $\mathrm{CpG}$ islands of bacterial and viral DNA. TLR engagement promotes inflammasome formation at least partially through signaling that activates the transcription factors NF- $\kappa \mathrm{B}$ and AP-1. TLR-induced inflammasomes facilitate IL-1 $\beta$ and IL-18 secretion as well as the expression of interferon regulatory factor (IRF) transcription factors that mediate type I interferon (IFN)-dependent antiviral responses. Sometimes a second signal is required to complete TLR-mediated inflammasome formation and induce IL-1 $\beta$ secretion. For example, although monocytes circulating in the blood can secrete IL- $1 \beta$ in response to LPS stimulation alone $(\mathrm{Ne}-$ tea et al. 2008), primary macrophages must undergo TLR engagement and receive an additional signal such as ATP before they can secrete IL$1 \beta$ (Wewers and Herzyk 1989; Herzyk et al. 1992). It is unclear whether TLRs are inflammasome components, or whether they act as signaling molecules for inflammasome formation.

NLRs. Members of the highly conserved NLR family participate in innate immune de- fense against infection in all animals as well as in plants (Jones and Dangl 2006). There are 22 NLR proteins in humans and even more in mice (Schroder and Tschopp 2010). The largest NLR subclass (14 members) contains the NLR pyrin domain-containing proteins (NLRPs). Other NLR family members include the NODs (NOD1 and NOD2), class II transactivator (CIITA), NAIP, and NLRX (Ting et al. 2008a). The amino terminus of NRL proteins is comprised of either a caspase recruitment domain (CARD) or a pyrin domain (PyD) that permits the direct or indirect recruitment of inflammatory procaspases. At the carboxyl terminus, all NRL proteins (except NLRP10) have a central NACHT domain followed by leucine-rich repeats (LRRs). These LRRs are believed to confer specificity for a particular PAMP/DAMP.

The first NLR to be characterized was CIITA, which is essential for MHC class II gene expression and currently the only NRL member that functions as a transcriptional activator. "Bare lymphocyte syndrome" in humans is owing to a loss-of-function mutation in the Ciita gene (Steimle et al. 1993). All other NRLs are thought to perform cytoplasmic surveillance for PAMPs/DAMPs.

NOD1 and NOD2 were the first NLRs reported to be PAMP PRRs. Both recognize products of bacterial peptidoglycan degradation, with NOD1 binding to mesodiaminopimelic acid derived mainly from Gram-negative bacteria (Chamaillard et al. 2003; Girardin et al. 2003a), and NOD2 detecting the muramyl dipeptide common to both Gram-negative and Gram-positive bacteria (Girardin et al. 2003b; Inohara et al. 2003). After engagement, NOD1 and NOD2 oligomerize and transiently recruit receptor-interacting protein 2 (RIP2) through CARD-CARD interaction, leading to NF- $\mathrm{kB}$ activation and proinflammatory gene expression (Kufer et al. 2005).

\section{Types of Inflammasomes}

NLRP3 Inflammasome. NLRP3 is a scaffold protein that uses $\mathrm{PyD}-\mathrm{PyD}$ interactions to bind to both ASC and procaspase-1, forming the NLRP3 inflammasome that promotes au- 
tocatalytic caspase- 1 activation. The NLRP3 inflammasome is expressed by myeloid cells and is formed ("activated") in response to a broad range of PAMPs as well as whole pathogens, including fungi (Jin and Flavell 2010). In the latter case, inflammasome activation involves Syk tyrosine kinase activity, the production of reactive oxygen species (ROS), and potassium efflux, but is independent of its transcriptional regulation of $I l-1 \beta$ (Gross et al. 2009). NLRP3 inflammasome activation is also triggered by bacteria such as Staphylococcus aureus and Listeria monocytogenes, which produce pore-forming toxins (Mariathasan et al. 2006); influenza virus, Sendai virus, and adenovirus, doublestranded RNA (Kanneganti et al. 2006; Muruve et al. 2008); and host-derived molecules such as ATP (Mariathasan et al. 2006) and hyaluronan (Yamasaki et al. 2009) that are released by injured cells. The NLRP3 inflammasome is also a sensor for amyloid- $\beta$ peptide, the accumulation of which is a hallmark of Alzheimer's disease (Halle et al. 2008). Noninfectious materials that activate the NLRP3 inflammasome include crystals of monosodium urate and calcium pyrophosphate dehydrate, which cause gout and pseudogout, respectively (Martinon et al. 2006); asbestos and crystalline silica (Cassel et al. 2008; Dostert et al. 2008); the skin irritants trinitrophenylcholride, trinitrochlorobenzene, and dinitrofluorobenzene (Sutterwala et al. 2006; Watanabe et al. 2007); and UVB radiation (Feldmeyer et al. 2007). It is surprising that a single molecule can "sense" all these different stimuli. A new hypothesis therefore states that this multitude of danger signals is integrated by mitochondria and that the NLRP3 monitors mitochondrial status, reacting to changes in $\mathrm{mi}-$ tochondrial activity that then trigger NLRP3 inflammasome formation (Tschopp 2011).

NLRC4 Inflammasome. The NLRC4 (NLR family, CARD domain-containing 4) inflammasome is formed in response to bacterial flagellin and conserved regions of the type III and type IV secretion systems of Gram-negative bacteria such as Salmonella typhimurium, Burkholderia pseudomallei (BsaK), Escherichia coli (EprJ and EscI), Shigella flexneri (MxiI), Pseudomonas aeruginosa (PscI), and Legionella pneumophila (Amer et al. 2006; Franchi et al. 2006, 2007; Miao et al. 2006, 2008, 2010; Molofsky et al. 2006; Sutterwala et al. 2007). The exact composition of the NLRC4 inflammasome is not fully understood and it is unclear if NLRC4 requires ASC for physiological caspase-1 activation (Poyet et al. 2001; Mariathasan et al. 2004; Franchi et al. 2007; Suzuki et al. 2007). The NLR member NAIP5 (NLR family, apoptosis inhibitory protein 5) is variably required for activation of this inflammasome (Lightfield et al. 2011).

NLRP1 Inflammasome. The NLRP1 inflammasome is activated in response to Bacillus anthracis lethal toxin (LeTx) (Boyden and Dietrich 2006) and muramyl dipeptide (MDP) (Faustin et al. 2007). The sequence of the NLRP1 gene has diverged between humans and rodents, and the murine genome contains three orthologues that are highly polymorphic (Boyden and Dietrich 2006). This variation is presumably responsible for the differences in LeTx susceptibility observed among inbred mouse strains (Boyden and Dietrich 2006). The precise mechanism by which the NLRP1 inflammasome induces caspase-1 activation is still controversial. Human NLRP1 contains a carboxy-terminal CARD domain and so can interact directly with procaspase-1; however, the addition of ASC to this complex in vitro increases inflammasome activity (Faustin et al. 2007). Notably, human NLRP1 can also bind to caspase-5 and thereby contribute to the processing of pro-IL$1 \beta$ and pro-IL-18 (Tschopp et al. 2003). In contrast, the mouse NLRP1 orthologues do not contain a functional PyD domain, and consequently NLRP1-associated caspase-1 activation in mouse macrophages is not dependent on ASC (Hsu et al. 2008).

Aim2 Inflammasome. Absent in melanoma 2 (AIM2) is a member of the pyrin and HIN domain-containing protein (PYHIN) family (Ludlow et al. 2005). AIM2 interacts with ASC through PyD-PyD interactions (Fernandes-Alnemri et al. 2009) to form an inflammasome that recruits and activates procaspase- 1 in response to cytosolic double-stranded DNA (dsDNA) (Fernandes-Alnemri et al. 2009; Hornung et al. 2009). AIM2 senses cytosolic DNA 
D.R. Mcllwain et al.

through its carboxy-terminal HIN-200 domain, which contains two oligonucleotide/oligosaccharide-binding folds (Fernandes-Alnemri et al. 2010). Because AIM2 does not contain a central oligomerization domain equivalent to the NACHT domain in NLRs, it is believed that the dsDNA ligand itself, which can bind to multiple AIM2 molecules, mediates AIM2 oligomerization in the inflammasome (FernandesAlnemri et al. 2009). Studies of gene-targeted Aim2-deficient mice have shown that, in addition to dsDNA, AIM2 detects the cytosolic bacterial pathogen Francisella tularensis (live vaccine strain) as well as DNA viruses such as vaccinia and mouse cytomegalovirus (mCMV) (Fernandes-Alnemri et al. 2010; Rathinam et al. 2010). Because it recognizes dsDNA, the AIM2 inflammasome may also play a role in the autoimmune responses to dsDNA characteristic of systemic lupus erythematosis (SLE) and related diseases (Fernandes-Alnemri et al. 2010; Rathinam et al. 2010).

\section{Caspase-1 and Cell Death}

Although caspase-1 activation most often contributes to inflammation, excessive caspase- 1 activity can cause pyroptosis, a nonapoptotic type of programmed cell death that is characterized by plasma membrane rupture and the release of proinflammatory intracellular contents (Cookson and Brennan 2001; Fink and Cookson 2006). Pyroptosis does not involve classical apoptotic caspases like caspase- 3 and -8. Instead, activated caspase- 1 activates caspase- 7 and an unidentified nuclease that induces DNA cleavage and nuclear condensation without compromising nuclear integrity (Molofsky et al. 2006; Bergsbaken and Cookson 2007). Because caspase- 1 activation is required for cell death in a variety of experimental settings, including in the immune system (Shi et al. 1996), the cardiovascular system (Kolodgie et al. 2000; Frantz et al. 2003), and the central nervous system (Liu et al. 1999; Yang et al. 1999; Zhang et al. 2003), pyroptosis has been thought to have an important physiological role. However, casp $1^{-/-}$mice develop normally, implying that this protease is redundant in vivo dur- ing development (Kuida et al. 1995; Li et al. 1995). Additional reports suggest that caspase1 is also capable of cleaving and activating BID and thereby engaging the mitochondrial pathway of apoptosis (Guegan et al. 2002; Zhang et al. 2003).

Recently it has been shown that caspase-1deficient mice show enhanced tumor formation in an azoxymethane and dextran sodium sulfate colitis-associated colorectal cancer model. Interestingly the mechanism of caspase-1 tumor formation in this model was not through regulation of inflammation, but rather owing to increased colonic epithelial cell proliferation in the early stages of tumor formation and reduced apoptosis in advanced tumors in the caspase-1deficient mice (Hu et al. 2010).

It should be noted that the interpretation of past data generated using caspase-1-deficient animals may need to be revisited in light of several new pieces of evidence. It has recently been shown that caspase-1-deficient mice generated from strain 129 embryonic stem cells also harbor a mutation in the caspase-11 locus, and so are de facto caspase-1/caspase-11 doubleknockout mice (Kayagaki et al. 2011). Kayagaki et al. addressed this issue in their study by rescuing caspase- 11 activity in their caspase-1-deficient mice via transgenic expression of a caspase-11 bacterial artificial chromosome. The in vivo data then generated indicate that caspase11 rather than caspase- 1 may be the critical effector caspase responsible for the inflammatory response, making human caspases- 4 and -5 potential interesting targets for intervention in patients with sepsis (Kayagaki et al. 2011).

\section{Caspase-12 and Anti-Inflammation}

In mice, caspase- 12 appears to abrogate the inflammatory response largely owing to an inhibitory effect on caspase-1 (Scott and Saleh 2007). Consequently, casp $12^{-/-}$mice show enhanced bacterial clearance and resistance to sepsis (Saleh et al. 2006). Interestingly, the enzymatic function of caspase-12 is not required for caspase-1 inhibition (Saleh et al. 2006), suggesting that caspase- 12 is more likely a protease regulator rather than a protease itself. 
In most humans from Eurasia and a significant proportion of individuals from African populations, there exists a frameshift mutation in the caspase-12 gene (CASP12) that generates a premature stop codon and prevents expression of full-length caspase-12 leading to a shortened caspase-12 protein (caspase-12S) (Fischer et al. 2002). However, in about $20 \%$ of individuals of sub-Saharan African descent, a single nucleotide polymorphism (SNP) changes this stop codon to an arginine residue, resulting in successful readthrough and the synthesis of the full-length caspase-12 protein (caspase-12L) (Saleh et al. 2004). Individuals expressing the readthrough polymorphism show reduced inflammatory and innate responses to endotoxins and thus an increased risk of developing severe sepsis (Saleh et al. 2004). It has been suggested that the rise in infectious disease that accompanied the increased population density developing in Europe over time favored the survival of individuals expressing the truncated caspase-12 variant (Xue et al. 2006).

\section{Caspases in Proliferation}

Although caspases are most often associated with apoptosis, there has been persistent evidence that some of these enzymes can also influence proliferation. One of the earliest observations was that treatment of $\mathrm{T}$ cells with caspase inhibitors led to a surprising suppression of CD3-induced T-cell expansion (Alam et al. 1999; Kennedy et al. 1999). This growthpromoting caspase function was later attributed to caspase- 8 , because c-FLIP, a caspase- 8 inhibitor, was shown to modulate T-cell proliferation (Lens et al. 2002). Similarly, caspase-8 and -6 can positively regulate B-cell proliferation (Olson et al. 2003; Beisner et al. 2005).

However, caspase- 3 may have the opposite effect, as B cells lacking caspase- 3 showed increased proliferation in vivo and hyperproliferation after mitogenic stimulation in vitro (Woo et al. 2003). This hyperproliferative B-cell phenotype was rescued in double-knockout mice lacking both caspase- 3 and the cyclin-dependent kinase inhibitor p21 (encoded by Cdkn1a), which is a caspase- 3 substrate (Woo et al. 2003).
As mentioned earlier, recent work has now provided convincing evidence that the suppression of RIPK signaling by caspase- 8 and FADD accounts for the nonapoptotic roles of these proteins (Kaiser et al. 2011; Oberst and Green 2011; Oberst et al. 2011; Zhang et al. 2011). Another important question, namely, how is it possible that the proteolytic function of caspase-8, which normally leads to apoptosis, can suppress RIPK signaling without causing apoptotic cell death, can also now be explained. CFLIP has a greater affinity for procaspase- 8 than this proenzyme has for itself, which permits CFLIP to inhibit the activation of apoptosis by caspase- 8 while allowing caspase- 8 to retain its catalytic activity (Boatright et al. 2004; Oberst and Green 2011).

\section{Less Well-Categorized Caspases}

\section{Caspase-2}

Caspase-2 is evolutionarily ancient, the most highly conserved caspase among animals, and one of the earliest caspases discovered (Kumar et al. 1994; Wang et al. 1994); its function resembles a more rudimentary type caspase similar to Caenorhabditis elegans in which it needs to fulfill multiple, sometimes opposing roles, that later during evolution have been taken over by other members of the caspase family.

The mammalian caspase- 2 protein has a long prodomain containing a CARD sequence. In response to apoptotic stimuli such as DNA damage, cytoskeletal disruption, metabolic perturbation, or heat shock (Harvey et al. 1997), inactive procaspase- 2 monomers are induced to oligomerize and are activated by induced proximity. The ensuing autocatalytic cleavage stabilizes the mature caspase-2 enzyme and enhances its activity (Baliga et al. 2004; Krumschnabel et al. 2009).

Procaspase-2 oligomerization is mediated by the adapter protein Rip-associated protein with a death domain (RAIDD), which binds to procaspase-2 via CARD-CARD interaction (Harvey et al. 1997; Baliga et al. 2004; Krumschnabel et al. 2009). Procaspase-2-bound RAIDD molecules form a complex via additional 
D.R. Mcllwain et al.

adapter molecules such as p53-induced protein with a DD (PIDD), which binds to RAIDD via DD-DD interaction. This PIDD-RAIDDprocaspase-2 complex has been termed the PIDDosome (Tinel and Tschopp 2004). Resolution of the crystal structure of the PIDDosome has revealed the presence of multiple PIDD and RAIDD subunits (Park and Wu 2006; Park et al. 2007) in a structure resembling the CD95FADD complex involved in procaspase- 8 activation.

Caspase- 2 can also be activated by a mechanism that involves p53-dependent CD95 up-regulation and the recruitment of caspase- 8 to the DISC complex. BID is cleaved by this coordination of caspase- 2 and -8 and mitochondrial apoptosis is activated (Sidi et al. 2008; Olsson et al. 2009). However, caspase- 2 is also involved in seemingly opposing functions such as protection against DNA damage (Shi et al. 2009) or cancer development (Ho et al. 2009). Caspase-2 is also important for programmed oocyte death during mouse development (Bergeron et al. 1998).

\section{Caspase-10}

Human caspase- 10 is highly homologous to caspase- 8 and is recruited to the DISC on DR engagement (Sprick et al. 2002). However, the role of caspase-10 in the extrinsic apoptotic cascade is still not clear. Reports have conflicted on the requirement for caspase-10 in CD95mediated apoptosis in the absence of caspase8 (Kischkel et al. 2001; Sprick et al. 2002). Although some recent findings suggest that caspase-10 acts in an atypical CD95-induced cell death pathway (Lafont et al. 2010), other evidence points to a role for caspase-10 in intrinsic apoptosis that is triggered by cytotoxic drugs in a fashion that is FADD-dependent but DR-independent (Park et al. 2004; Filomenko et al. 2006; Lee et al. 2007). To date, no mouse caspase-10 homolog has been reported.

\section{Caspase-14}

Caspase-14 is unique because it is found only in terrestrial mammals and does not seem to have evolved from orthologues in insects or nema- todes like the apoptotic caspases (Lamkanfi et al. 2002). Furthermore, caspase-14 expression is restricted to cornifying epithelial cells, such as occur in the skin, and plays a role in terminal keratinocyte differentiation (Denecker et al. 2008). Studies of casp $14^{-/-}$mice have shown that caspase- 14 is responsible for both the correct processing of profilaggrin during cornification and the protection of mice against UVB irradiation (Denecker et al. 2007). However, caspase-14 is dispensable for keratinocyte apoptosis (Denecker et al. 2008).

\section{CASPASES IN HUMAN DISEASE}

Caspase activity is a double-edged sword. Although defective caspase activation and the inadequate cell death that results can promote tumorigenesis, extreme caspase activation and the excessive cell death that ensues can promote neurodegenerative conditions. Furthermore, insufficient activation of caspases involved in inflammation can lead to an increased succeptibility to infection, whereas hyperactivation of these caspases can promote inflammatory conditions.

\section{Caspases and Cancer}

Our bodies use several sophisticated mechanisms to safeguard against cancer development. These mechanisms recognize DNA mutations, and induce either the repair of the faulty DNA, or the death of the affected cell before it can become oncogenic. Because caspases are crucial for apoptosis, it is not surprising that deregulation of these enzymes and the pathways in which they are involved can aid in the persistence of mutated cells and promote tumorigenesis. However, although caspases are key players in the best documented mechanism of cancer cell death, unlike mutation of p53 or elements of the PI3K pathway, mutation of CASP genes is not frequent in human tumor cells. Genetic and inhibitor studies have shown that the inactivation of individual caspases is not usually sufficient to either prevent continuation of the caspase cascade, or to derail alternative nonapoptotic cell death mechanisms. Instead, 
malignant cells appear to more frequently gain a survival advantage by inactivating signaling mediators upstream of caspase activation.

Despite the above, the reduced expression of proapoptotic caspases has been reported in a variety of cancers (Philchenkov et al. 2004), and specific inactivating mutations have been linked to various tumor types and stages of transformation (discussed below). Moreover, although inherited mutations in the CASP genes are relatively rare, certain caspase polymorphisms thought to affect caspase abundance or activity have been associated with variable effects on tumorigenesis.

\section{Caspase- 8}

Inactivating CASP8 mutations have been reported in various cancers, including childhood neuroblastoma. Wild-type caspase- 8 acts as a tumor suppressor in neuroblastomas with amplification of N-myc (Teitz et al. 2000), thus mutations leading to loss of caspase- 8 function render neuroblastoma cell lines resistant to DRinduced apoptosis (Hopkins-Donaldson et al. 2000; Teitz et al. 2000; Eggert et al. 2001; Yang et al. 2003). Furthermore, in an experimental neuroblastoma cell line model, caspase- 8 deletion enhanced the metastatic potential of neuroblastoma cells in chick embryos (Stupack et al. 2006).

In a study of 180 human colorectal tumors (98 invasive carcinomas and 82 adenomas), somatic CASP8 mutations were detected in $5 \%$ of invasive carcinomas but in no adenomas. At least three of the mutations were confirmed to decrease caspase-8-mediated apoptosis by acting in a dominant-negative fashion (Kim et al. 2003). In a similar study of 69 hepatocellular carcinomas (HCCs), a single somatic CASP8 mutation was detected in nine cases (13.0\%). This frameshift mutation resulted in a two base-pair deletion (1225_1226delTG) that caused premature termination of translation and loss of caspase- 8 function (Soung et al. $2005 b$ ). In another study of 162 gastric carcinomas (40 early and 122 advanced cancers), 185 non-small-cell lung cancers, 93 breast carcinomas, and 88 acute leukemias, CASP 8 mutations were detected only in advanced gastric cancers (10.7\%) (Soung et al. 2005a). Again, these mutations led to markedly decreased caspase-8-dependent cell death in vitro (Soung et al. 2005b).

An interesting linkage between CASP8 and cancer occurs for inheritance of the D302H polymorphism in CASP8 (rs1045485), which substitutes histidine for aspartic acid and is associated with reduced breast cancer risk (MacPherson et al. 2004; Frank et al. 2005). An analysis of 16,423 cases and 17,109 controls from 14 studies conducted by the Breast Cancer Association Consortium (BCAC) has confirmed the dose-dependent protective effect of this allele [ $P$ trend $=1.1 \times 10^{-7}$, per allele odds ratio $(\mathrm{OR})=0.88$, with a $95 \%$ confidence interval (CI) of 0.84-0.92] (Cox et al. 2007). Another well-studied inherited CASP8 polymorphism is a six-nucleotide deletion $(-6526 \mathrm{~N}$ del; $6 \mathrm{~N}$ del, rs3834129) in the promoter region. A recent meta-analysis of 23 publications covering 55,174 cancer cases and 59,336 controls from 55 individual studies concluded that the $\mathrm{D} 302 \mathrm{H}$ variant and the $-6526 \mathrm{~N}$ del polymorphism were associated with a significantly reduced overall risk of cancer (Yin et al. 2010). It is assumed that these alterations to the mutated caspase- 8 protein enhance its proapoptotic effects and prevent tumor cell persistence, although such a relationship has yet to be shown in vivo.

\section{Caspase-9}

Germline variation in the CASP9 gene has been linked to non-Hodgkin's lymphoma (NHL) (Kelly et al. 2010). In a study of 36 apoptosis pathway genes, alterations of CASP9 at both the gene and SNP levels were associated with NHL risk (Kelly et al. 2010). In another study of the impact on lymphomagenesis of genetic variation in 12 caspases, examination of $1946 \mathrm{NHL}$ cases and 1808 controls showed significant associations for alterations of CASP8, CASP9, or CASP1 with NHL (Lan et al. 2009). An earlier smaller study of 461 NHL cases and 535 controls also showed a significant association between certain variants of CASP3 and CASP9 and NHL risk (Lan et al. 2007). In both studies, the caspase-9 SNPs associated with NHL 
D.R. Mcllwain et al.

showed decreased risk of NHL, whereas the other caspases showed increased NHL risk.

In an analysis of polymorphisms in the CASP9 promoter in 432 lung cancer patients and 432 matched controls, the -1263 GG genotype was linked to a significantly decreased risk of lung cancer compared with the -1263 AA genotype or the $-1263 \mathrm{AA}+\mathrm{AG}$ genotype (Park et al. 2006). It was proposed that this protective effect might be owing to increased promoter activity of the G-C haplotype compared with the $-1263 \mathrm{G} /-712 \mathrm{~T}$ and $-1263 \mathrm{~A} /-712 \mathrm{C}$ haplotypes that enhances caspase-9 expression (Park et al. 2006).

\section{Caspase-3}

Many studies have analyzed whether alterations to the CASP3 gene encoding the crucial executioner caspase- 3 might promote human tumorigenesis. One study examined the caspase-3 coding region in 944 tumors of 14 different types compared with healthy adjacent tissue. However, only 14 tumors (1.48\%) showed somatic CASP3 mutations (Soung et al. 2004). In another study analyzing 930 squamous cell carcinomas of the head and neck (SCCHN) and 993 controls, the CASP3 rs4647601:TT variant was associated with an increased risk of SCCHN compared with the GG genotype (Chen et al. 2008a). This finding was most evident in certain subgroups, including younger ( $\leq 56 \mathrm{yr})$ subjects, males, and never smokers. Conversely, in an analysis of 582 lung cancer patients and 582 controls, individuals bearing at least one allele with a $-928 \mathrm{~A}>\mathrm{G}, 77 \mathrm{G}>\mathrm{A}$, or $17532 \mathrm{~A}>\mathrm{C}$ polymorphism had a significantly decreased risk for lung cancer compared with individuals who were homozygous for the wild-type CASP3 allele (Jang et al. 2008).

An important study of 128 multiple myeloma cases and 516 controls analyzed five SNPs in various CASP genes. Compared with individuals with the TT genotype of CASP3 Ex8 $+567 \mathrm{~T}>\mathrm{C}$, subjects with the CC genotype had a fivefold lower risk of multiple myeloma (Hosgood et al. 2008). Multiple myeloma risk was also reduced in individuals with the $A G$ and AA genotypes of CASP9 Ex $5+32 \mathrm{G}>\mathrm{A}$
(Hosgood et al. 2008). An earlier study by the same group found a similar association between decreased risk of NHL and certain CASP3 variants (Lan et al. 2007). Finally, a study of 1028 endometrial cancer patients and 1003 healthy controls examined potential links between caspase- $3,-7$, and -8 variant alleles and risk of endometrial cancer. Compared with the CC genotype, the GG genotype of rs2705901 in CASP3 was significantly associated with increased cancer risk (Xu et al. 2009). Taken together, these results suggest that CASP3 polymorphisms and their haplotypes help to define an individual's genetic susceptibility to cancer development.

\section{Caspase-7}

In one analysis of multiple cancer types, somatic mutations in CASP7 were detected in two of 98 colon carcinomas $(2.0 \%)$, one of 50 esophageal carcinomas $(2.0 \%)$, and one of 33 head/neck carcinomas (3.0\%), but not in stomach, urinary bladder, or lung cancers (Soung et al. 2003). When these tumor-derived caspase-7 mutants were overexpressed in 293T human kidney cells, the cells showed reduced apoptosis (Soung et al. 2003). In a different study of 720 lung cancer patients and 720 controls, certain CASP7 polymorphisms were found to promote susceptibility to lung cancer (Lee et al. 2009b). As mentioned earlier, a study of 1028 endometrial cancer patients and 1003 healthy controls examined potential links between caspase- $3,-7$, and -8 variant alleles and risk of endometrial cancer. Of 35 selected SNPs, four in CASP7 were in high linkage disequilibrium and associated with increased risk of endometrial cancer; two CASP7 SNPs were associated with reduced risk; and two CASP7 SNPs were associated with increased risk compared with individuals homozygous for the major CASP7 alleles. These findings suggest that mutations altering the executioner function of caspase- 7 affect the pathogenesis of some human solid cancers.

\section{Caspase-1, -4, -5}

An evaluation of mutations in the inflammatory caspases- $1,-4$, and -5 in 337 samples of 
various types of human cancers showed that CASP1 mutations were present in two malignancies $(0.6 \%)$, CASP4 mutations in two $(0.6 \%)$, and CASP5 mutations in $15(4.4 \%)$ (Soung et al. 2008). The highest prevalence of CASP5 mutations was in microsatellite instability (MSI)-positive gastric carcinomas, suggesting that caspase- 5 activity may be important in the etiology of these tumors.

In a mouse model of colorectal cancer based on colitis induced by azoxymethane and dextran sodium sulfate treatment, casp $1^{-/-}$mutants showed enhanced tumor formation owing to alterations to two different caspase functions. In early-stage tumors, the proliferation of colonic epithelial cells was increased in the absence of caspase-1, whereas in advanced tumors, apoptosis was reduced (Hu et al. 2010). Interestingly, despite the association of caspase- 1 with inflammation, in neither early nor late colorectal tumors was defective regulation of inflammation observed.

\section{Caspase-6}

CASP6 mutations have been found in 2\% of 150 human cancers of colonic or gastric origin (Lee et al. 2006). Furthermore, expression of caspase- 6 in gastric cancer samples is decreased, suggesting that loss of caspase- 6 expression might be involved in the mechanism of gastric cancer development (Yoo et al. 2004).

\section{Caspase-10}

An analysis of 117 NHL samples revealed that 17 (14.5\%) contained inactivating CASP10 mutations (Shin et al. 2002). When overexpressed in 293T cells, these mutations suppressed apoptosis. Rare CASP10 mutations have also been detected in cases of T-cell acute lymphoblastic leukemia and multiple myeloma (Kim et al. 2009), as well as in colon, breast, lung, and hepatocellular carcinomas (Oh et al. 2010) and gastric cancers (Park et al. 2002).

\section{Caspase-1 in Inflammatory Diseases}

The production of IL-1, and thus caspase-1 activation, has been implicated in a wide variety of inflammatory and autoimmune diseases ( $\mathrm{Ga}$ bay et al. 2010). Researchers have frequently sought to confirm the involvement of caspase1 in these conditions through the use of agents that attempt to modulate IL-1 production by blocking caspase-1, IL-1 functions, or IL-1 receptors. However, human trials of agents targeting IL-1 in rheumatoid arthritis (RA) (Drevlow et al. 1996; Bresnihan et al. 1998; Jiang et al. 2000; Cohen et al. 2002; Genovese et al. 2004; Alten et al. 2008), as well as in other rheumatic diseases such as SLE, psoriatic arthritis, and osteoarthritis (Finckh and Gabay 2008), have shown only modest efficacy or no improvement. Nevertheless, these drugs have improved the health of patients with several other hereditary and acquired conditions linked to elevated IL$1 \beta$ levels, as outlined below.

\section{Gout}

Gout is a common autoinflammatory disorder characterized by chronic elevated blood uric acid levels (hyperuricemia) and the deposition of monosodium urate (MSU) crystals in joints. Patients experience severe pain and joint inflammation. The pathogenesis of this disease, as well as that of pseudogout (deposition of calcium pyrophosphate dihydrate crystals) and pulmonary silicosis, have been linked to inflammatory responses activated by the deposited crystals and mediated by the NLRP3 inflammasome (Cronstein and Terkeltaub 2006; Martinon et al. 2006; Hornung et al. 2008).

\section{Cryopyrin-Associated Periodic Syndromes}

Mutations in NLRP3 cause three rare inherited autoinflammatory diseases known collectively as cryopyrin-associated periodic syndromes (CAPS) (Hoffman et al. 2001; Aksentijevich et al. 2002; Feldmann et al. 2002). These disorders are, in order of increasing severity, familial cold autoinflammatory syndrome (FCAS), MuckleWells syndrome (MWS), and neonatal-onset multisystem inflammatory disease (NOMID), which is also referred to as chronic infantile neurologic cutaneous articular (CINCA) syndrome. Gene-targeted mice harboring Nlrp3 
D.R. Mcllwain et al.

mutations equivalent to those found in FCAS and MWS patients have hyperactive NLRP3 inflammasome activity and elevated IL-1 $\beta$ levels (Brydges et al. 2009; Meng et al. 2009).

\section{Type 2 Diabetes}

Type 2 diabetes (T2D) occurs when insulin production by pancreatic islet $\beta$ cells fails to compensate for insulin resistance. Elevated IL-1 $\beta$ levels are a risk factor for T2D development (Spranger et al. 2003) and contribute to insulin resistance (Maedler et al. 2009). Excessive caspase- 1 activity has thus been implicated in T2D etiology.

\section{Familial Mediterranean Fever}

Familial Mediterranean fever (FMF) is an autoinflammatory disease caused by mutations in the Mediterranean fever gene (MEFV) that encodes the pyrin protein (Chae et al. 2008). The most severe form of FMF arises from missense mutations affecting the carboxy-terminal B30.2/SPRY domain of pyrin, which is important for its interaction with procaspase-1 (Chae et al. 2006; Papin et al. 2007). However, there is conflicting evidence on whether pyrin mutations affect IL- $1 \beta$ production (Chae et al. 2003, 2006; Yu et al. 2006; Seshadri et al. 2007). Treatment with an IL-1 targeting agent (see below) has induced symptom regression in FMF patients, implying a causative role for IL-1 $\beta$ in this disease (Roldan et al. 2008).

\section{Pyogenic Sterile Arthritis, Pyoderma Gangrenosum, and Acne Syndrome}

Pyogenic sterile arthritis, pyoderma gangrenosum, and acne (PAPA) syndrome is a rare autosomal-dominant genetic disorder caused by mutations in the CD2-binding protein 1 (CD2BP1) gene. Patients suffer from severe, juvenile-onset arthritis, pyoderma gangrenosum, and acne. These mutations disrupt the binding of (CD2BP1) to protein tyrosine phosphatase, nonreceptor type 12 (PTPN 12) (Wise et al. 2002), thereby increasing CD2BP1 binding to pyrin. Association with CD2BP1 reduces pyrin's ability to inhibit inappropriate inflammasome activation (Shoham et al. 2003).

\section{Hyperimmunoglobulinemia D with Periodic Fever Syndrome}

Hyperimmunoglobulinemia D with periodic fever syndrome (HIDS) is a rare autosomal-recessive disorder (van der Meer et al. 1984) that is thought to be caused by mutations in the gene encoding mevalonate kinase (Drenth et al. 1999; Houten et al. 1999). HIDS patients show increased blood levels of IL-1 $\beta$ and IgD. Mevalonate kinase deficiency (MKD), an autosomalrecessive disorder characterized by recurring episodes of inflammation, leads to decreased production of nonsterol isoprenoid end products, in particular, geranylgeranyl groups (Mandey et al. 2006). Isoprenoid deficiency can induce PI3K pathway-dependent procaspase-1 activation, leading to increased IL- $1 \beta$ production (Kuijk et al. 2008).

\section{Systemic-Onset Juvenile Idiopathic Arthritis}

The pathophysiology of systemic-onset juvenile idiopathic arthritis (sJIA), which affects an estimated 250,000 children in the United States alone, and which presents itself with initial systemic symptoms such as fever, anemia, leukocytosis, and elevated erythrocyte sedimentation rate (ESR), has been linked to elevated levels of IL-1 $\beta$ (Pascual et al. 2005).

\section{Caspases in Other Diseases}

\section{Alzheimer's Disease}

Neuronal death in a variety of neurodegenerative diseases, including Alzheimer's disease (AD), has been associated with deregulated caspase activation (Rohn and Head 2009). However, several lines of evidence suggest that the role of caspases in $\mathrm{AD}$ may involve more than just action as cellular executioners driven by upstream disease processes. Caspase-mediated cleavage of $\beta$-amyloid precursor protein (APP) has been reported (Rohn et al. 2001), as has caspase activation by amyloid- $\beta$ peptide (O’Brien and Wong 2011). In 
one murine AD model, caspase activation associated with disease onset occurred earlier than the induction of neuronal apoptosis (D'Amelio et al. 2011). Similarly, caspase activation has been noted before the development of neurofibrillary tangles of Tau in the brain of tau transgenic mice (de Calignon et al. 2010).

\section{Kawasaki Disease}

Kawasaki disease (KD) is an acute vasculitis syndrome that predominantly affects arteries in young children (Kawasaki 1967; Burns 2002). In one study, a $\mathrm{G}$ to A substitution in a particular SNP located in the $5^{\prime}$ untranslated region of CASP3 abolished the binding of the nuclear factor of activated T cells (NFAT) transcription factor to the DNA sequence surrounding the SNP, suggesting that altered CASP3 expression in immune effector cells can influence KD susceptibility (Onouchi et al. 2010). However, another study of $341 \mathrm{KD}$ patients and 751 controls found an association of only borderline significance between this CASP3 polymorphism and KD $(P=0.0535$ under the dominant model; $P=$ 0.0575 under the allelic model) (Kuo et al. 2011).

\section{Autoimmune Lymphoproliferative Syndrome}

Autoimmune lymphoproliferative syndrome (ALPS) causes lymphoadenopathy, splenomegaly, autoimmune hemolytic anemia, thrombocytopenia, and hypergammaglobinemia in children (Lenardo et al. 1999; Straus et al. 1999). The majority of ALPS patients have dominant mutations in CD95, CD95L, or CASP10 (Lenardo et al. 1999; Straus et al. 1999; Wang et al. 1999). It is thought that ALPS may be caused by insufficient apoptosis of autoreactive $\mathrm{T}$ cells during negative thymic selection (Fleisher 2008).

\section{CASPASES IN DISEASE THERAPY}

Activating Caspases to Promote Cell Death

\section{Cancer}

Several attempts have been made within the last decade to develop molecules capable of directly activating caspase- 3 for use in cancer therapy. A particular target suggested for intervention has been the "safety catch" sequence present in inactive procaspase-3 (Roy et al. 2001). This sequence is a triplet of aspartic acid residues that maintains the intramolecular electrostatic interactions that keep procaspase- 3 in an inactive state in resting cells (Roy et al. 2001). Highthroughput screening (HTS) projects have identified a series of molecules, including $\alpha$-(trichloromethyl)-4-pyridineethanol (PETCM), gambonic acid, and the gambonic acid derivative MX-2060, that efficiently activate caspase-3 in vitro (Jiang et al. 2003; Zhang et al. 2004; Fischer and Schulze-Osthoff 2005). This series has shown promise in inducing the apoptosis of cancer cell lines, but no clinical development of these agents has been reported. Another promising caspase- 3 activator identified by HTS is first procaspase-activating compound (PAC-1), which contains a zinc-chelating motif (Putt et al. 2006). This motif is critical to PAC1 's ability to activate caspase-3 (Peterson et al. 2009). Recent in vivo canine studies using a "next-generation" compound (S-PAC-1) have been efficacious, and treatments induced partial tumor regression (Peterson et al. 2010). However, the mechanism of PAC-1-mediated caspase activation is controversial because another group was unable to confirm the results obtained by Putt et al. (Putt et al. 2006). Denault et al. (2007) have suggested instead that PAC-1 cannot directly activate executioner caspases but rather uses an indirect and therefore blunted and less effective activation mechanism.

Another area of active research concentrates on compounds that activate caspases indirectly. Some of these agents block endogenous caspase inhibitors such as the Bcl-2 and IAP proteins (Vogler et al. 2009), whereas others are analogs of the endogenous IAP inhibitor Smac (Chen and Huerta 2009). Still others are activators and antibodies that engage DRs (Ying Lu 2011). Several of these compounds are currently under examination in clinical trials.

It should be noted that the use of apoptosisinducing compounds for cancer treatment is not new, and most of these agents are subject to the same limitations of delivery and specificity as traditional chemotherapeutics. However, 
D.R. Mcllwain et al.

certain caspase activators, such as those that inhibit antiapoptotic molecules like Bcl-2, appear to have an enhanced therapeutic index when used to treat cancer cells that rely mainly on antiapoptotic proteins to stave off cell death (Certo et al. 2006).

\section{Graft versus Host Disease}

Another situation in which induction of cell death might be advantageous is the elimination of autoreactive lymphocytes in graft versus host disease (GVHD). Patients are currently being recruited for a phase I/II clinical trial of a modified version of caspase-9. This inducible caspase-9 "safety switch" agent consists of a truncated caspase- 9 protein that lacks the CARD domain and is fused to a forkhead protein binding sequence. In the presence of a particular small molecule, the caspase- 9 safety switch protein dimerizes and activates the hydrolytic function of the enzyme, triggering apoptosis (Straathof et al. 2005). When used as a therapy, the caspase- 9 safety switch is virally transduced into allodepleted T cells, which are then administered to patients who have received a T-celldepleted stem cell transplant (Tey et al. 2007). Should GVHD occur following the transplant, the small molecule is administered to the patient to induce caspase- 9 activation and quickly eliminate autoreactive T cells via apoptosis.

\section{Inhibiting Caspases to Prevent Cell Death}

In general, the inhibition of caspase activity has had less striking therapeutic effects than has caspase activation. Nevertheless, there are several instances in which, regardless of whether caspases have been definitively implicated in the etiology or pathological consequences of a disease, caspase inhibition has ameliorated the symptoms of several conditions caused by inappropriate apoptotic cell death. For example, because chronic hepatitis virus $\mathrm{C}$ infection is accompanied by detrimental hepatocyte apoptosis, a recent clinical trial examined the therapeutic potential of a caspase inhibitor (Manns 2010). Similarly, the severity of ischemia reperfusion injury resulting from cell death that often follows a stroke (Renolleau et al. 2007), traumatic brain injury (Knoblach et al. 2004), or organ transplant (Baskin-Bey et al. 2007) can be reduced by caspase inhibition. Last, because the neuronal death characteristic of $\mathrm{AD}$ and other neurodegenerative diseases, as well as possibly other aspects of disease progression, are associated with caspase activation (see above), caspase inhibitors are under investigation in mouse models of $\mathrm{AD}$ and have already shown promising results (O’Brien and Wong 2011).

\section{IL-1 $\beta$ Antagonism}

A key component of many inflammatory disorders appears to be the activation of caspase- 1 leading to the generation of active IL-1 $\beta$. Accordingly, agents that can antagonize either the generation or function of IL- $1 \beta$ or its receptor (IL-1R) have been developed for patient treatment. An early such agent was Anakinra, a small molecule antagonist of IL-1R. Newer agents include monoclonal antibodies (mAbs) directed against IL-1 $\beta$ (canakinumab) (Alten et al. 2008; Church and McDermott 2009; Lachmann et al. 2009a), and IL-1Trap, a decoy receptor with high affinity for IL-1 (Kalliolias and Liossis 2008).

Clinical trials are currently under way to assess the efficacy of the above inhibitors and related molecules as treatment for several of the inflammatory diseases discussed above. For example, patients with gout, pseudogout, or pulmonary silicosis have shown great improvement after treatment with an IL-1 $\beta$ antagonist (McGonagle et al. 2007, 2008; So et al. 2007; Terkeltaub et al. 2009). CAPS patients also respond well to IL-1 $\beta$ antagonists (Hawkins et al. 2003, 2004a,b; Hoffman et al. 2004, 2008; Goldbach-Mansky et al. 2006, 2008; Hoffman 2009; Lachmann et al. 2009b), although the disease is also ameliorated by caspase-1 inhibition (Stack et al. 2005). IL-1 $\beta$ antagonists have also shown efficacy in clinical trials for the treatment of T2D (Larsen et al. 2007, 2009), confirming the important role of the NLRP3 inflammasome containing caspase- 1 as a sensor of metabolic stress (Schroder and Tschopp 2010). Lastly, IL-1 $\beta$ antagonists have induced symptom regression in 
FMF patients (Roldan et al. 2008), HIDS patients (Cailliez et al. 2006), and sJIA patients (Pascual et al. 2005; Kelly and Ramanan 2008; Lequerre et al. 2008).

\section{CONCLUSION}

In conclusion, caspase family members are at the nexus of critical regulatory networks controlling cell death and inflammation. We know that although caspase activity is critical for homeostasis of organisms, cells must take steps to protect themselves against unintended caspase activation through complex systems required to turn inactive caspase zymogens into functional proteases. The long list of diseases associated with caspases tells us that the inappropriate activation of caspases and dysregulation of the cell death and inflammatory pathways they control has dire consequences for human health. A growing body of research is providing us with ever increasing clarity about how these exciting proteases operate and how we might fight disease by manipulating their functions.

\section{REFERENCES}

Acehan D, Jiang X, Morgan DG, Heuser JE, Wang X, Akey CW. 2002. Three-dimensional structure of the apoptosome: Implications for assembly, procaspase- 9 binding, and activation. Mol Cell 9: 423-432.

Aksentijevich I, Nowak M, Mallah M, Chae JJ, Watford WT, Hofmann SR, Stein L, Russo R, Goldsmith D, Dent P, et al. 2002. De novo CIAS1 mutations, cytokine activation, and evidence for genetic heterogeneity in patients with neonatal-onset multisystem inflammatory disease (NOMID): A new member of the expanding family of pyrin-associated autoinflammatory diseases. Arthritis Rheum 46: 3340-3348.

Alam A, Cohen LY, Aouad S, Sekaly RP. 1999. Early activation of caspases during $\mathrm{T}$ lymphocyte stimulation results in selective substrate cleavage in nonapoptotic cells. J Exp Med 190: 1879-1890.

Alten R, Gram H, Joosten LA, van den Berg WB, Sieper J, Wassenberg S, Burmester G, van Riel P, Diaz-Lorente M, Bruin GJ, et al. 2008. The human anti-IL-1 $\beta$ monoclonal antibody ACZ885 is effective in joint inflammation models in mice and in a proof-of-concept study in patients with rheumatoid arthritis. Arthritis Res Ther 10: R67.

Amer A, Franchi L, Kanneganti TD, Body-Malapel M, Ozoren N, Brady G, Meshinchi S, Jagirdar R, Gewirtz A, Akira S, et al. 2006. Regulation of Legionella phagosome maturation and infection through flagellin and host Ipaf. J Biol Chem 281: 35217-35223.
Anderson KV, Bokla L, Nusslein-Volhard C. 1985a. Establishment of dorsal-ventral polarity in the Drosophila embryo: The induction of polarity by the Toll gene product. Cell 42: 791-798.

Anderson KV, Jurgens G, Nusslein-Volhard C. 1985b. Establishment of dorsal-ventral polarity in the Drosophila embryo: Genetic studies on the role of the Toll gene product. Cell 42: 779-789.

Arai J, Katai N, Kuida K, Kikuchi T, Yoshimura N. 2006. Decreased retinal neuronal cell death in caspase- 1 knockout mice. Jpn J Ophthalmol 50: 417-425.

Baliga BC, Read SH, Kumar S. 2004. The biochemical mechanism of caspase-2 activation. Cell Death Differ 11: 1234-1241.

Baskin-Bey ES, Washburn K, Feng S, Oltersdorf T, Shapiro D, Huyghe M, Burgart L, Garrity-Park M, van Vilsteren FG, Oliver LK, et al. 2007. Clinical trial of the pan-caspase inhibitor, IDN-6556, in human liver preservation injury. Am J Transplant 7: 218-225.

Beisner DR, Ch'en IL, Kolla RV, Hoffmann A, Hedrick SM. 2005. Cutting edge: Innate immunity conferred by B cells is regulated by caspase-8. J Immunol 175: 3469-3473.

Bergeron L, Perez GI, Macdonald G, Shi L, Sun Y, Jurisicova A, Varmuza S, Latham KE, Flaws JA, Salter JC, et al. 1998. Defects in regulation of apoptosis in caspase-2-deficient mice. Genes Dev 12: 1304-1314.

Bergsbaken T, Cookson BT. 2007. Macrophage activation redirects yersinia-infected host cell death from apoptosis to caspase-1-dependent pyroptosis. PLoS Pathog 3: el61.

Boatright KM, Renatus M, Scott FL, Sperandio S, Shin H, Pedersen IM, Ricci JE, Edris WA, Sutherlin DP, Green DR et al. 2003. A unified model for apical caspase activation. Mol Cell 11: 529-541.

Boatright KM, Deis C, Denault JB, Sutherlin DP, Salvesen GS. 2004. Activation of caspases- 8 and -10 by FLIP(L). Biochem J 382: 651-657.

Boyden ED, Dietrich WF. 2006. Nalp1b controls mouse macrophage susceptibility to anthrax lethal toxin. Nat Genet 38: 240-244.

Brenner D, Mak TW. 2009. Mitochondrial cell death effectors. Curr Opin Cell Biol 21: 871-877.

Bresnihan B, Alvaro-Gracia JM, Cobby M, Doherty M, Domljan Z, Emery P, Nuki G, Pavelka K, Rau R, Rozman B, et al. 1998. Treatment of rheumatoid arthritis with recombinant human interleukin-1 receptor antagonist. Arthritis Rheum 41: 2196-2204.

Brydges SD, Mueller JL, McGeough MD, Pena CA, Misaghi A, Gandhi C, Putnam CD, Boyle DL, Firestein GS, Horner AA, et al. 2009. Inflammasome-mediated disease animal models reveal roles for innate but not adaptive immunity. Immunity 30: 875-887.

Burns JC. 2002. Commentary: Translation of Dr. Tomisaku Kawasaki's original report of fifty patients in 1967. Pediatr Infect Dis J 21: 993-995.

Cailliez M, Garaix F, Rousset-Rouviere C, Bruno D, KonePaut I, Sarles J, Chabrol B, Tsimaratos M. 2006. Anakinra is safe and effective in controlling hyperimmunoglobulinaemia D syndrome-associated febrile crisis. J Inherit Metab Dis 29: 763. 
D.R. Mcllwain et al.

Cain K, Bratton SB, Cohen GM. 2002. The Apaf-1 apoptosome: A large caspase-activating complex. Biochimie 84: 203-214.

Cassel SL, Eisenbarth SC, Iyer SS, Sadler JJ, Colegio OR, Tephly LA, Carter AB, Rothman PB, Flavell RA, Sutterwala FS. 2008. The Nalp3 inflammasome is essential for the development of silicosis. Proc Natl Acad Sci 105: 9035-9040.

Certo M, Del Gaizo Moore V, Nishino M, Wei G, Korsmeyer S, Armstrong SA, Letai A. 2006. Mitochondria primed by death signals determine cellular addiction to antiapoptotic BCL-2 family members. Cancer Cell 9: 351-365.

Chae JJ, Komarow HD, Cheng J, Wood G, Raben N, Liu PP, Kastner DL. 2003. Targeted disruption of pyrin, the FMF protein, causes heightened sensitivity to endotoxin and a defect in macrophage apoptosis. Mol Cell 11: 591-604.

Chae JJ, Wood G, Masters SL, Richard K, Park G, Smith BJ, Kastner DL. 2006. The B30.2 domain of pyrin, the familial Mediterranean fever protein, interacts directly with caspase- 1 to modulate IL-1 $\beta$ production. Proc Natl Acad Sci 103: 9982-9987.

Chae JJ, Wood G, Richard K, Jaffe H, Colburn NT, Masters SL, Gumucio DL, Shoham NG, Kastner DL. 2008. The familial Mediterranean fever protein, pyrin, is cleaved by caspase- 1 and activates NF- $\mathrm{B}$ through its N-terminal fragment. Blood 112: 1794-1803.

Chamaillard M, Hashimoto M, Horie Y, Masumoto J, Qiu S, Saab L, Ogura Y, Kawasaki A, Fukase K, Kusumoto S, et al. 2003. An essential role for NOD1 in host recognition of bacterial peptidoglycan containing diaminopimelic acid. Nat Immunol 4: 702-707.

Chang DW, Xing Z, Capacio VL, Peter ME, Yang X. 2003. Interdimer processing mechanism of procaspase-8 activation. $E M B O J$ J 22: 4132-4142.

Chen DJ, Huerta S. 2009. Smac mimetics as new cancer therapeutics. Anticancer Drugs 20: 646-658.

Chen K, Zhao H, Hu Z, Wang LE, Zhang W, Sturgis EM, Wei Q. 2008a. CASP3 polymorphisms and risk of squamous cell carcinoma of the head and neck. Clin Cancer Res 14: 6343-6349.

Chen NJ, Chio II, Lin WJ, Duncan G, Chau H, Katz D, Huang HL, Pike KA, Hao Z, Su YW, et al. 2008b. Beyond tumor necrosis factor receptor: TRADD signaling in tolllike receptors. Proc Natl Acad Sci 105: 12429-12434.

Chun HJ, Zheng L, Ahmad M, Wang J, Speirs CK, Siegel RM, Dale JK, Puck J, Davis J, Hall CG, et al. 2002. Pleiotropic defects in lymphocyte activation caused by caspase- 8 mutations lead to human immunodeficiency. Nature 419: 395-399.

Church LD, McDermott MF. 2009. Canakinumab, a fullyhuman $\mathrm{mAb}$ against IL- $1 \beta$ for the potential treatment of inflammatory disorders. Curr Opin Mol Ther 11: 81-89.

Cohen S, Hurd E, Cush J, Schiff M, Weinblatt ME, Moreland LW, Kremer J, Bear MB, Rich WJ, McCabe D. 2002. Treatment of rheumatoid arthritis with anakinra, a recombinant human interleukin-1 receptor antagonist, in combination with methotrexate: Results of a twentyfour-week, multicenter, randomized, double-blind, placebo-controlled trial. Arthritis Rheum 46: 614-624.

Cookson BT, Brennan MA. 2001. Pro-inflammatory programmed cell death. Trends Microbiol 9: 113-114.
Cox A, Dunning AM, Garcia-Closas M, Balasubramanian S, Reed MW, Pooley KA, Scollen S, Baynes C, Ponder BA, Chanock S, et al. 2007. A common coding variant in CASP8 is associated with breast cancer risk. Nat Genet 39: $352-358$.

Cronstein BN, Terkeltaub R. 2006. The inflammatory process of gout and its treatment. Arthritis Res Ther 8: S3.

D’Amelio M, Cavallucci V, Middei S, Marchetti C, Pacioni S, Ferri A, Diamantini A, De Zio D, Carrara P, Battistini L, et al. 2011. Caspase-3 triggers early synaptic dysfunction in a mouse model of Alzheimer's disease. Nat Neurosci 14: 69-76.

Davis BK, Wen H, Ting JP. 2011. The inflammasome NLRs in immunity, inflammation, and associated diseases. Annu Rev Immunol 29: 707-735.

de Calignon A, Fox LM, Pitstick R, Carlson GA, Bacskai BJ, Spires-Jones TL, Hyman BT. 2010. Caspase activation precedes and leads to tangles. Nature 464: 1201-1204.

Denault JB, Drag M, Salvesen GS, Alves J, Heidt AB, Deveraux Q, Harris JL. 2007. Small molecules not direct activators of caspases. Nat Chem Biol 3: 519; author reply 520.

Denecker G, Hoste E, Gilbert B, Hochepied T, Ovaere P, Lippens S, Van den Broecke C, Van Damme P, D’Herde K, Hachem JP, et al. 2007. Caspase-14 protects against epidermal UVB photodamage and water loss. Nat Cell Biol 9: 666-674.

Denecker G, Ovaere P, Vandenabeele P, Declercq W. 2008. Caspase-14 reveals its secrets. J Cell Biol 180: 451-458.

Dostert C, Petrilli V, Van Bruggen R, Steele C, Mossman BT, Tschopp J. 2008. Innate immune activation through Nalp3 inflammasome sensing of asbestos and silica. Science 320: 674-677.

Drenth JP, Cuisset L, Grateau G, Vasseur C, van de VeldeVisser SD, de Jong JG, Beckmann JS, van der Meer JW, Delpech M, International Hyper-IgD Study Group. 1999. Mutations in the gene encoding mevalonate kinase cause hyper-IgD and periodic fever syndrome. Nat Genet 22: $178-181$.

Drevlow BE, Lovis R, Haag MA, Sinacore JM, Jacobs C, Blosche C, Landay A, Moreland LW, Pope RM. 1996. Recombinant human interleukin-1 receptor type I in the treatment of patients with active rheumatoid arthritis. Arthritis Rheum 39: 257-265.

Eggert A, Grotzer MA, Zuzak TJ, Wiewrodt BR, Ho R, Ikegaki N, Brodeur GM. 2001. Resistance to tumor necrosis factor-related apoptosis-inducing ligand (TRAIL)induced apoptosis in neuroblastoma cells correlates with a loss of caspase-8 expression. Cancer Res 61: 1314-1319.

Faubel S, Ljubanovic D, Reznikov L, Somerset H, Dinarello CA, Edelstein CL. 2004. Caspase-1-deficient mice are protected against cisplatin-induced apoptosis and acute tubular necrosis. Kidney Int 66: 2202-2213.

Faustin B, Lartigue L, Bruey JM, Luciano F, Sergienko E, Bailly-Maitre B, Volkmann N, Hanein D, Rouiller I, Reed JC. 2007. Reconstituted NALP1 inflammasome reveals two-step mechanism of caspase- 1 activation. $\mathrm{Mol}$ Cell 25: 713-724.

Feldmann J, Prieur AM, Quartier P, Berquin P, Certain S, Cortis E, Teillac-Hamel D, Fischer A, de Saint Basile G. 2002. Chronic infantile neurological cutaneous and articular syndrome is caused by mutations in CIAS1, a gene 
highly expressed in polymorphonuclear cells and chondrocytes. Am J Hum Genet 71: 198-203.

Feldmeyer L, Keller M, Niklaus G, Hohl D, Werner S, Beer HD. 2007. The inflammasome mediates UVB-induced activation and secretion of interleukin- $1 \beta$ by keratinocytes. Curr Biol 17: 1140-1145.

Fernandes-Alnemri T, Yu JW, Datta P, Wu J, Alnemri ES. 2009. AIM2 activates the inflammasome and cell death in response to cytoplasmic DNA. Nature 458: 509-513.

Fernandes-Alnemri T, Yu JW, Juliana C, Solorzano L, Kang S, Wu J, Datta P, McCormick M, Huang L, McDermott E, et al. 2010. The AIM2 inflammasome is critical for innate immunity to Francisella tularensis. Nat Immunol 11: 385-393.

Filomenko R, Prevotat L, Rebe C, Cortier M, Jeannin JF, Solary E, Bettaieb A. 2006. Caspase-10 involvement in cytotoxic drug-induced apoptosis of tumor cells. Oncogene 25: 7635-7645.

Finckh A, Gabay C. 2008. At the horizon of innovative therapy in rheumatology: New biologic agents. Curr Opin Rheumatol 20: 269-275.

Fink SL, Cookson BT. 2006. Caspase-1-dependent pore formation during pyroptosis leads to osmotic lysis of infected host macrophages. Cell Microbiol 8: 1812-1825.

Fischer U, Schulze-Osthoff K. 2005. New approaches and therapeutics targeting apoptosis in disease. Pharmacol Rev 57: 187-215.

Fischer H, Koenig U, Eckhart L, Tschachler E. 2002. Human caspase 12 has acquired deleterious mutations. Biochem Biophys Res Commun 293: 722-726.

Fleisher TA. 2008. The autoimmune lymphoproliferative syndrome: An experiment of nature involving lymphocyte apoptosis. Immunol Res 40: 87-92.

Franchi L, Amer A, Body-Malapel M, Kanneganti TD, Ozoren N, Jagirdar R, Inohara N, Vandenabeele P, Bertin J, Coyle A, et al. 2006. Cytosolic flagellin requires Ipaf for activation of caspase- 1 and interleukin $1 \beta$ in salmonellainfected macrophages. Nat Immunol 7: 576-582.

Franchi L, Stoolman J, Kanneganti TD, Verma A, Ramphal R, Nunez G. 2007. Critical role for Ipaf in Pseudomonas aeruginosa-induced caspase-1 activation. Eur $J$ Immunol 37: 3030-3039.

Frank B, Bermejo JL, Hemminki K, Klaes R, Bugert P, Wappenschmidt B, Schmutzler RK, Burwinkel B. 2005. Re: Association of a common variant of the CASP8 gene with reduced risk of breast cancer. J Natl Cancer Inst 97: 1012; author reply 1012-1013.

Frantz S, Ducharme A, Sawyer D, Rohde LE, Kobzik L, Fukazawa R, Tracey D, Allen H, Lee RT, Kelly RA. 2003. Targeted deletion of caspase-1 reduces early mortality and left ventricular dilatation following myocardial infarction. J Mol Cell Cardiol 35: 685-694.

Gabay C, Lamacchia C, Palmer G. 2010. IL-1 pathways in inflammation and human diseases. Nat Rev Rheumatol 6: 232-241.

Genovese MC, Cohen S, Moreland L, Lium D, Robbins S, Newmark R, Bekker P. 2004. Combination therapy with etanercept and anakinra in the treatment of patients with rheumatoid arthritis who have been treated unsuccessfully with methotrexate. Arthritis Rheum 50: 1412-1419.
Girardin SE, Boneca IG, Carneiro LA, Antignac A, Jehanno M, Viala J, Tedin K, Taha MK, Labigne A, Zahringer $\mathrm{U}$, et al. 2003a. Nod1 detects a unique muropeptide from gram-negative bacterial peptidoglycan. Science 300: $1584-1587$.

Girardin SE, Boneca IG, Viala J, Chamaillard M, Labigne A, Thomas G, Philpott DJ, Sansonetti PJ. 2003b. Nod2 is a general sensor of peptidoglycan through muramyl dipeptide (MDP) detection. J Biol Chem 278: 8869-8872.

Goldbach-Mansky R, Dailey NJ, Canna SW, Gelabert A, Jones J, Rubin BI, Kim HJ, Brewer C, Zalewski C, Wiggs E, et al. 2006. Neonatal-onset multisystem inflammatory disease responsive to interleukin- $1 \beta$ inhibition. N Engl J Med 355: 581-592.

Goldbach-Mansky R, Shroff SD, Wilson M, Snyder C, Plehn S, Barham B, Pham TH, Pucino F, Wesley RA, Papadopoulos JH, et al. 2008. A pilot study to evaluate the safety and efficacy of the long-acting interleukin-1 inhibitor rilonacept (interleukin-1 Trap) in patients with familial cold autoinflammatory syndrome. Arthritis Rheum 58: 2432-2442.

Gross O, Poeck H, Bscheider M, Dostert C, Hannesschlager N, Endres S, Hartmann G, Tardivel A, Schweighoffer E, Tybulewicz V, et al. 2009. Syk kinase signalling couples to the Nlrp3 inflammasome for anti-fungal host defence. Nature 459: 433-436.

Guegan C, Vila M, Teismann P, Chen C, Onteniente B, Li M, Friedlander RM, Przedborski S. 2002. Instrumental activation of bid by caspase- 1 in a transgenic mouse model of ALS. Mol Cell Neurosci 20: 553-562.

Hakem R, Hakem A, Duncan GS, Henderson JT, Woo M, Soengas MS, Elia A, de la Pompa JL, Kagi D, Khoo W, et al. 1998. Differential requirement for caspase 9 in apoptotic pathways in vivo. Cell 94: 339-352.

Halle A, Hornung V, Petzold GC, Stewart CR, Monks BG, Reinheckel T, Fitzgerald KA, Latz E, Moore KJ, Golenbock DT. 2008. The NALP3 inflammasome is involved in the innate immune response to amyloid- $\beta$. Nat Immunol 9: $857-865$.

Hao Z, Duncan GS, Chang CC, Elia A, Fang M, Wakeham A, Okada H, Calzascia T, Jang Y, You-Ten A, et al. 2005. Specific ablation of the apoptotic functions of cytochrome $c$ reveals a differential requirement for cytochrome $c$ and Apaf-1 in apoptosis. Cell 121: 579-591.

Harvey NL, Butt AJ, Kumar S. 1997. Functional activation of Nedd2/ICH-1 (caspase-2) is an early process in apoptosis. J Biol Chem 272: 13134-13139.

Hawkins PN, Lachmann HJ, McDermott MF. 2003. Interleukin-1-receptor antagonist in the Muckle-Wells syndrome. N Engl J Med 348: 2583-2584.

Hawkins PN, Bybee A, Aganna E, McDermott MF. 2004a. Response to anakinra in a de novo case of neonatal-onset multisystem inflammatory disease. Arthritis Rheum 50: 2708-2709.

Hawkins PN, Lachmann HJ, Aganna E, McDermott MF. 2004b. Spectrum of clinical features in Muckle-Wells syndrome and response to anakinra. Arthritis Rheum 50: 607-612.

Herzyk DJ, Allen JN, Marsh CB, Wewers MD. 1992. Macrophage and monocyte IL- $1 \beta$ regulation differs at multiple sites. Messenger RNA expression, translation, and posttranslational processing. J Immunol 149: 3052-3058. 
D.R. Mcllwain et al.

Ho LH, Taylor R, Dorstyn L, Cakouros D, Bouillet P, Kumar S. 2009. A tumor suppressor function for caspase-2. Proc Natl Acad Sci 106: 5336-5341.

Hoffman HM. 2009. Rilonacept for the treatment of cryopyrin-associated periodic syndromes (CAPS). Expert Opin Biol Ther 9: 519-531.

Hoffman HM, Mueller JL, Broide DH, Wanderer AA, Kolodner RD. 2001. Mutation of a new gene encoding a putative pyrin-like protein causes familial cold autoinflammatory syndrome and Muckle-Wells syndrome. Nat Genet 29: 301-305.

Hoffman HM, Rosengren S, Boyle DL, Cho JY, Nayar J, Mueller JL, Anderson JP, Wanderer AA, Firestein GS. 2004. Prevention of cold-associated acute inflammation in familial cold autoinflammatory syndrome by interleukin-1 receptor antagonist. Lancet 364: 1779-1785.

Hoffman HM, Throne ML, Amar NJ, Sebai M, Kivitz AJ, Kavanaugh A, Weinstein SP, Belomestnov P, Yancopoulos GD, Stahl N, et al. 2008. Efficacy and safety of rilonacept (interleukin-1 Trap) in patients with cryopyrin-associated periodic syndromes: Results from two sequential placebo-controlled studies. Arthritis Rheum 58: $2443-2452$.

Hopkins-Donaldson S, Bodmer JL, Bourloud KB, Brognara CB, Tschopp J, Gross N. 2000. Loss of caspase- 8 expression in highly malignant human neuroblastoma cells correlates with resistance to tumor necrosis factorrelated apoptosis-inducing ligand-induced apoptosis. Cancer Res 60: 4315-4319.

Hornung V, Bauernfeind F, Halle A, Samstad EO, Kono H, Rock KL, Fitzgerald KA, Latz E. 2008. Silica crystals and aluminum salts activate the NALP3 inflammasome through phagosomal destabilization. Nat Immunol 9: 847-856.

Hornung V, Ablasser A, Charrel-Dennis M, Bauernfeind F, Horvath G, Caffrey DR, Latz E, Fitzgerald KA. 2009. AIM2 recognizes cytosolic dsDNA and forms a caspase1-activating inflammasome with ASC. Nature 458: 514518.

Hosgood HD 3rd, Baris D, Zhang Y, Zhu Y, Zheng T, Yeager M, Welch R, Zahm S, Chanock S, Rothman N, et al. 2008. Caspase polymorphisms and genetic susceptibility to multiple myeloma. Hematol Oncol 26: 148-151.

Houten SM, Kuis W, Duran M, de Koning TJ, van RoyenKerkhof A, Romeijn GJ, Frenkel J, Dorland L, de Barse MM, Huijbers WA, et al. 1999. Mutations in MVK, encoding mevalonate kinase, cause hyperimmunoglobulinaemia D and periodic fever syndrome. Nat Genet 22: 175-177.

Hsu LC, Ali SR, McGillivray S, Tseng PH, Mariathasan S, Humke EW, Eckmann L, Powell JJ, Nizet V, Dixit VM, et al. 2008. A NOD2-NALP1 complex mediates caspase1-dependent IL-1 $\beta$ secretion in response to Bacillus anthracis infection and muramyl dipeptide. Proc Natl Acad Sci 105: 7803-7808.

$\mathrm{Hu}$ B, Elinav E, Huber S, Booth CJ, Strowig T, Jin C, Eisenbarth SC, Flavell RA. 2010. Inflammation-induced tumorigenesis in the colon is regulated by caspase- 1 and NLRC4. Proc Natl Acad Sci 107: 21635-21640.

Inohara N, Ogura Y, Fontalba A, Gutierrez O, Pons F, Crespo J, Fukase K, Inamura S, Kusumoto S, Hashimoto M, et al. 2003. Host recognition of bacterial mur- amyl dipeptide mediated through NOD2. Implications for Crohn's disease. J Biol Chem 278: 5509-5512.

Jang JS, Kim KM, Choi JE, Cha SI, Kim CH, Lee WK, Kam S, Jung TH, Park JY. 2008. Identification of polymorphisms in the Caspase-3 gene and their association with lung cancer risk. Mol Carcinog 47: 383-390.

Jiang Y, Genant HK, Watt I, Cobby M, Bresnihan B, Aitchison R, McCabe D. 2000. A multicenter, doubleblind, dose-ranging, randomized, placebo-controlled study of recombinant human interleukin-1 receptor antagonist in patients with rheumatoid arthritis: Radiologic progression and correlation of Genant and Larsen scores. Arthritis Rheum 43: 1001-1009.

Jiang X, Kim HE, Shu H, Zhao Y, Zhang H, Kofron J, Donnelly J, Burns D, Ng SC, Rosenberg S, et al. 2003. Distinctive roles of PHAP proteins and prothymosin- $\alpha$ in a death regulatory pathway. Science 299: 223-226.

Jin C, Flavell RA. 2010. Molecular mechanism of NLRP3 inflammasome activation. J Clin Immunol 30: 628-631.

Jones JD, Dangl JL. 2006. The plant immune system. Nature 444: 323-329.

Jost PJ, Grabow S, Gray D, McKenzie MD, Nachbur U, Huang DC, Bouillet P, Thomas HE, Borner C, Silke J, et al. 2009. XIAP discriminates between type I and type II FAS-induced apoptosis. Nature 460: 1035-1039.

Juo P, Kuo CJ, Yuan J, Blenis J. 1998. Essential requirement for caspase-8/FLICE in the initiation of the Fas-induced apoptotic cascade. Curr Biol 8: 1001-1008.

Kaiser WJ, Upton JW, Long AB, Livingston-Rosanoff D, Daley-Bauer LP, Hakem R, Caspary T, Mocarski ES. 2011. RIP3 mediates the embryonic lethality of caspase8-deficient mice. Nature 471: 368-372.

Kalliolias GD, Liossis SN. 2008. The future of the IL-1 receptor antagonist anakinra: From rheumatoid arthritis to adult-onset Still's disease and systemic-onset juvenile idiopathic arthritis. Expert Opin Investig Drugs 17: 349359.

Kang TB, Ben-Moshe T, Varfolomeev EE, Pewzner-Jung Y, Yogev N, Jurewicz A, Waisman A, Brenner O, Haffner R, Gustafsson E, et al. 2004. Caspase-8 serves both apoptotic and nonapoptotic roles. J Immunol 173: 2976-2984.

Kanneganti TD, Body-Malapel M, Amer A, Park JH, Whitfield J, Franchi L, Taraporewala ZF, Miller D, Patton JT, Inohara N, et al. 2006. Critical role for Cryopyrin/Nalp3 in activation of caspase-1 in response to viral infection and double-stranded RNA. J Biol Chem 281: 3656036568.

Kawasaki T. 1967. Acute febrile mucocutaneous syndrome with lymphoid involvement with specific desquamation of the fingers and toes in children. Arerugi 16: 178-222.

Kayagaki N, Warming S, Lamkanfi M, Vande Walle L, Louie S, Dong J, Newton K, Qu Y, Liu J, Heldens S, et al. 2011. Non-canonical inflammasome activation targets caspase-11. Nature 479: 117-121.

Kelly A, Ramanan AV. 2008. A case of macrophage activation syndrome successfully treated with anakinra. Nat Clin Pract Rheumatol 4: 615-620.

Kelly JL, Novak AJ, Fredericksen ZS, Liebow M, Ansell SM, Dogan A, Wang AH, Witzig TE, Call TG, Kay NE, et al. 2010. Germline variation in apoptosis pathway genes and 
risk of non-Hodgkin's lymphoma. Cancer Epidemiol Biomarkers Prev 19: 2847-2858.

Kennedy NJ, Kataoka T, Tschopp J, Budd RC. 1999. Caspase activation is required for T cell proliferation. J Exp Med 190: 1891-1896.

Kim HS, Lee JW, Soung YH, Park WS, Kim SY, Lee JH, Park JY, Cho YG, Kim CJ, Jeong SW, et al. 2003. Inactivating mutations of caspase- 8 gene in colorectal carcinomas. Gastroenterology 125: 708-715.

Kim MS, Oh JE, Min CK, Lee S, Chung NG, Yoo NJ, Lee SH 2009. Mutational analysis of CASP10 gene in acute leukaemias and multiple myelomas. Pathology 41: 484-487.

Kischkel FC, Lawrence DA, Tinel A, LeBlanc H, Virmani A, Schow P, Gazdar A, Blenis J, Arnott D, Ashkenazi A. 2001. Death receptor recruitment of endogenous caspase- 10 and apoptosis initiation in the absence of caspase-8. $J$ Biol Chem 276: 46639-46646.

Knoblach SM, Alroy DA, Nikolaeva M, Cernak I, Stoica BA, Faden AI. 2004. Caspase inhibitor z-DEVD-fmk attenuates calpain and necrotic cell death in vitro and after traumatic brain injury. J Cereb Blood Flow Metab 24: 1119-1132.

Kolodgie FD, Narula J, Burke AP, Haider N, Farb A, HuiLiang Y, Smialek J, Virmani R. 2000. Localization of apoptotic macrophages at the site of plaque rupture in sudden coronary death. Am J Pathol 157: 1259-1268.

Kovalenko A, Kim JC, Kang TB, Rajput A, Bogdanov K, Dittrich-Breiholz O, Kracht M, Brenner O, Wallach D. 2009. Caspase-8 deficiency in epidermal keratinocytes triggers an inflammatory skin disease. J Exp Med 206: 2161-2177.

Krumschnabel G, Manzl C, Villunger A. 2009. Caspase-2: Killer, savior and safeguard-Emerging versatile roles for an ill-defined caspase. Oncogene 28: 3093-3096.

Kufer TA, Fritz JH, Philpott DJ. 2005. NACHT-LRR proteins (NLRs) in bacterial infection and immunity. Trends Microbiol 13: 381-388.

Kuida K, Lippke JA, Ku G, Harding MW, Livingston DJ, Su MS, Flavell RA. 1995. Altered cytokine export and apoptosis in mice deficient in interleukin- $1 \beta$ converting enzyme. Science 267: 2000-2003.

Kuida K, Zheng TS, Na S, Kuan C, Yang D, Karasuyama H, Rakic P, Flavell RA. 1996. Decreased apoptosis in the brain and premature lethality in CPP32-deficient mice. Nature 384: 368-372.

Kuida K, Haydar TF, Kuan CY, Gu Y, Taya C, Karasuyama H, Su MS, Rakic P, Flavell RA. 1998. Reduced apoptosis and cytochrome $c$-mediated caspase activation in mice lacking caspase 9. Cell 94: 325-337.

Kuijk LM, Beekman JM, Koster J, Waterham HR, Frenkel J, Coffer PJ. 2008. HMG-CoA reductase inhibition induces IL- $1 \beta$ release through Rac1/PI3K/PKB-dependent caspase-1 activation. Blood 112: 3563-3573.

Kumar S, Kinoshita M, Noda M, Copeland NG, Jenkins NA. 1994. Induction of apoptosis by the mouse Nedd2 gene, which encodes a protein similar to the product of the Caenorhabditis elegans cell death gene ced- 3 and the mammalian IL-1 $\beta$-converting enzyme. Genes Dev 8: $1613-1626$

Kuo HC, Yu HR, Juo SH, Yang KD, Wang YS, Liang CD, Chen WC, Chang WP, Huang CF, Lee CP, et al.
2011. CASP3 gene single-nucleotide polymorphism (rs72689236) and Kawasaki disease in Taiwanese children. J Hum Genet 56: 161-165.

Lachmann HJ, Kone-Paut I, Kuemmerle-Deschner JB, Leslie KS, Hachulla E, Quartier P, Gitton X, Widmer A, Patel N, Hawkins PN. 2009a. Use of canakinumab in the cryopyrin-associated periodic syndrome. $N$ Engl J Med 360: $2416-2425$.

Lachmann HJ, Lowe P, Felix SD, Rordorf C, Leslie K, Madhoo S, Wittkowski H, Bek S, Hartmann N, Bosset S, et al. 2009b. In vivo regulation of interleukin $1 \beta$ in patients with cryopyrin-associated periodic syndromes. $J$ Exp Med 206: 1029-1036.

Lafont E, Milhas D, Teissie J, Therville N, AndrieuAbadie N, Levade T, Benoist H, Segui B. 2010. Caspase10-dependent cell death in Fas/CD95 signalling is not abrogated by caspase inhibitor zVAD-fmk. PLoS ONE 5: e13638.

Lakhani SA, Masud A, Kuida K, Porter GA Jr, Booth CJ, Mehal WZ, Inayat I, Flavell RA. 2006. Caspases 3 and 7: Key mediators of mitochondrial events of apoptosis. Science 311: 847-851.

Lamkanfi M, Declercq W, Kalai M, Saelens X, Vandenabeele P. 2002. Alice in caspase land. A phylogenetic analysis of caspases from worm to man. Cell Death Differ 9: $358-361$.

Lan Q, Zheng T, Chanock S, Zhang Y, Shen M, Wang SS, Berndt SI, Zahm SH, Holford TR, Leaderer B, et al. 2007. Genetic variants in caspase genes and susceptibility to non-Hodgkin lymphoma. Carcinogenesis 28: 823-827.

Lan Q, Morton LM, Armstrong B, Hartge P, Menashe I, Zheng T, Purdue MP, Cerhan JR, Zhang Y, Grulich A, et al. 2009. Genetic variation in caspase genes and risk of non-Hodgkin lymphoma: A pooled analysis of 3 population-based case-control studies. Blood 114: 264-267.

Larsen CM, Faulenbach M, Vaag A, Volund A, Ehses JA, Seifert B, Mandrup-Poulsen T, Donath MY. 2007. Interleukin-1-receptor antagonist in type 2 diabetes mellitus. N Engl J Med 356: 1517-1526.

Larsen CM, Faulenbach M, Vaag A, Ehses JA, Donath MY, Mandrup-Poulsen T. 2009. Sustained effects of interleukin-1 receptor antagonist treatment in type 2 diabetes. Diabetes Care 32: 1663-1668.

Lee JW, Kim MR, Soung YH, Nam SW, Kim SH, Lee JY, Yoo NJ, Lee SH. 2006. Mutational analysis of the CASP6 gene in colorectal and gastric carcinomas. APMIS 114: 646-650.

Lee HJ, Pyo JO, Oh Y, Kim HJ, Hong SH, Jeon YJ, Kim H, Cho DH, Woo HN, Song S, et al. 2007. AK2 activates a novel apoptotic pathway through formation of a complex with FADD and caspase-10. Nat Cell Biol 9: 1303-1310.

Lee P, Lee DJ, Chan C, Chen SW, Ch'en I, Jamora C. 2009a. Dynamic expression of epidermal caspase 8 simulates a wound healing response. Nature 458: 519-523.

Lee WK, Kim JS, Kang HG, Cha SI, Kim DS, Hyun DS, Kam S, Kim CH, Jung TH, Park JY. 2009b. Polymorphisms in the Caspase7 gene and the risk of lung cancer. Lung Cancer 65: 19-24.

Lenardo M, Chan KM, Hornung F, McFarland H, Siegel R, Wang J, Zheng L. 1999. Mature T lymphocyte apoptosis-Immune regulation in a dynamic and unpredictable antigenic environment. Annu Rev Immunol 17: 221-253. 
D.R. Mcllwain et al.

Lens SM, Kataoka T, Fortner KA, Tinel A, Ferrero I, MacDonald RH, Hahne M, Beermann F, Attinger A, Orbea HA, et al. 2002. The caspase 8 inhibitor c-FLIP(L) modulates T-cell receptor-induced proliferation but not activation-induced cell death of lymphocytes. Mol Cell Biol 22: 5419-5433.

Lequerre T, Quartier P, Rosellini D, Alaoui F, De Bandt M, Mejjad O, Kone-Paut I, Michel M, Dernis E, Khellaf M, et al. 2008. Interleukin-1 receptor antagonist (anakinra) treatment in patients with systemic-onset juvenile idiopathic arthritis or adult onset Still disease: Preliminary experience in France. Ann Rheum Dis 67: 302-308.

Li P, Allen H, Banerjee S, Franklin S, Herzog L, Johnston C, McDowell J, Paskind M, Rodman L, Salfeld J, et al. 1995. Mice deficient in IL- $1 \beta$-converting enzyme are defective in production of mature IL- $1 \beta$ and resistant to endotoxic shock. Cell 80: 401-411.

Li J, Brieher WM, Scimone ML, Kang SJ, Zhu H, Yin H, von Andrian UH, Mitchison T, Yuan J. 2007. Caspase-11 regulates cell migration by promoting Aip1-Cofilin-mediated actin depolymerization. Nat Cell Biol 9: 276-286.

Li C, Lasse S, Lee P, Nakasaki M, Chen SW, Yamasaki K, Gallo RL, Jamora C. 2010. Development of atopic dermatitis-like skin disease from the chronic loss of epidermal caspase-8. Proc Natl Acad Sci 107: 22249-22254.

Lightfield KL, Persson J, Trinidad NJ, Brubaker SW, Kofoed EM, Sauer JD, Dunipace EA, Warren SE, Miao EA, Vance RE. 2011. Differential requirements for NAIP5 in activation of the NLRC4 (IPAF) inflammasome. Infect Immun 79: 1606-1614.

Liu XH, Kwon D, Schielke GP, Yang GY, Silverstein FS, Barks JD. 1999. Mice deficient in interleukin-1 converting enzyme are resistant to neonatal hypoxic-ischemic brain damage. J Cereb Blood Flow Metab 19: 1099-1108.

Loo YM, Gale M Jr. 2011. Immune signaling by RIG-I-like receptors. Immunity 34: 680-692.

Ludlow LE, Johnstone RW, Clarke CJ. 2005. The HIN-200 family: More than interferon-inducible genes? Exp Cell Res 308: 1-17.

MacPherson G, Healey CS, Teare MD, Balasubramanian SP, Reed MW, Pharoah PD, Ponder BA, Meuth M, Bhattacharyya NP, Cox A. 2004. Association of a common variant of the CASP8 gene with reduced risk of breast cancer. J Natl Cancer Inst 96: 1866-1869.

Madden SD, Cotter TG. 2008. Cell death in brain development and degeneration: Control of caspase expression may be key! Mol Neurobiol 37: 1-6.

Maedler K, Dharmadhikari G, Schumann DM, Storling J. 2009. Interleukin- $1 \beta$ targeted therapy for type 2 diabetes. Expert Opin Biol Ther 9: 1177-1188.

Mandey SH, Kuijk LM, Frenkel J, Waterham HR. 2006. A role for geranylgeranylation in interleukin- $1 \beta$ secretion. Arthritis Rheum 54: 3690-3695.

Manns EL, Hoepelman AIM, Choi HJ, Lee JY, Cornpropst M, Liang W, King B, Hirsch KR, Oldach D, Rousseau FS. 2010. Short term safety, tolerability, pharmacokinetics and preliminary activity of GS 9450 , a selective caspase inhibitor, in patients with chronic HCV infection. In 45th Annual Meeting of the European Association for the Study of the Liver (EASL 2010), Vienna, Austria.
Mariathasan S, Newton K, Monack DM, Vucic D, French DM, Lee WP, Roose-Girma M, Erickson S, Dixit VM. 2004. Differential activation of the inflammasome by caspase-1 adaptors ASC and Ipaf. Nature 430: 213-218.

Mariathasan S, Weiss DS, Newton K, McBride J, O'Rourke K, Roose-Girma M, Lee WP, Weinrauch Y, Monack DM, Dixit VM. 2006. Cryopyrin activates the inflammasome in response to toxins and ATP. Nature 440: $228-232$.

Martinon F, Burns K, Tschopp J. 2002. The inflammasome: A molecular platform triggering activation of inflammatory caspases and processing of proIL- $\beta$. Mol Cell 10: 417-426.

Martinon F, Petrilli V, Mayor A, Tardivel A, Tschopp J. 2006. Gout-associated uric acid crystals activate the NALP3 inflammasome. Nature 440: 237-241.

McGonagle D, Tan AL, Shankaranarayana S, Madden J, Emery P, McDermott MF. 2007. Management of treatment resistant inflammation of acute on chronic tophaceous gout with anakinra. Ann Rheum Dis 66: 16831684.

McGonagle D, Tan AL, Madden J, Emery P, McDermott MF. 2008. Successful treatment of resistant pseudogout with anakinra. Arthritis Rheum 58: 631-633.

Medzhitov R, Preston-Hurlburt P, Janeway CA Jr. 1997. A human homologue of the Drosophila Toll protein signals activation of adaptive immunity. Nature 388: 394-397.

Meng G, Zhang F, Fuss I, Kitani A, Strober W. 2009. A mutation in the Nlrp3 gene causing inflammasome hyperactivation potentiates Th17 cell-dominant immune responses. Immunity 30: 860-874.

Merkle S, Frantz S, Schon MP, Bauersachs J, Buitrago M, Frost RJ, Schmitteckert EM, Lohse MJ, Engelhardt S. 2007. A role for caspase-1 in heart failure. Circ Res 100: 645-653.

Miao EA, Alpuche-Aranda CM, Dors M, Clark AE, Bader MW, Miller SI, Aderem A. 2006. Cytoplasmic flagellin activates caspase- 1 and secretion of interleukin $1 \beta$ via Ipaf. Nat Immunol 7: 569-575.

Miao EA, Ernst RK, Dors M, Mao DP, Aderem A. 2008. Pseudomonas aeruginosa activates caspase 1 through Ipaf. Proc Natl Acad Sci 105: 2562-2567.

Miao EA, Mao DP, Yudkovsky N, Bonneau R, Lorang CG, Warren SE, Leaf IA, Aderem A. 2010. Innate immune detection of the type III secretion apparatus through the NLRC4 inflammasome. Proc Natl Acad Sci 107: 3076-3080.

Molofsky AB, Byrne BG, Whitfield NN, Madigan CA, Fuse ET, Tateda K, Swanson MS. 2006. Cytosolic recognition of flagellin by mouse macrophages restricts $\mathrm{Le}$ gionella pneumophila infection. J Exp Med 203: $1093-$ 1104.

Monie TP, Bryant CE, Gay NJ. 2009. Activating immunity: Lessons from the TLRs and NLRs. Trends Biochem Sci 34: 553-561.

Muruve DA, Petrilli V, Zaiss AK, White LR, Clark SA, Ross PJ, Parks RJ, Tschopp J. 2008. The inflammasome recognizes cytosolic microbial and host DNA and triggers an innate immune response. Nature 452: 103-107. 
Muzio M, Stockwell BR, Stennicke HR, Salvesen GS, Dixit VM. 1998. An induced proximity model for caspase-8 activation. J Biol Chem 273: 2926-2930.

Nakagawa T, Zhu H, Morishima N, Li E, Xu J, Yankner BA, Yuan J. 2000. Caspase-12 mediates endoplasmic-reticulum-specific apoptosis and cytotoxicity by amyloid- $\beta$. Nature 403: 98-103.

Netea MG, van de Veerdonk FL, Kullberg BJ, Van der Meer JW, Joosten LA. 2008. The role of NLRs and TLRs in the activation of the inflammasome. Expert Opin Biol Ther 8: 1867-1872.

Oberst A, Green DR. 2011. It cuts both ways: Reconciling the dual roles of caspase 8 in cell death and survival. Nat Rev Mol Cell Biol 12: 757-763.

Oberst A, Dillon CP, Weinlich R, McCormick LL, Fitzgerald P, Pop C, Hakem R, Salvesen GS, Green DR. 2011. Catalytic activity of the caspase-8-FLIP(L) complex inhibits RIPK3-dependent necrosis. Nature 471: 363367.

O’Brien RJ, Wong PC. 2011. Amyloid precursor protein processing and Alzheimer's disease. Ann Rev Neurosci 34: 185-204.

Oh JE, Kim MS, Ahn CH, Kim SS, Han JY, Lee SH, Yoo NJ. 2010. Mutational analysis of CASP10 gene in colon, breast, lung and hepatocellular carcinomas. Pathology 42: $73-76$

Olson NE, Graves JD, Shu GL, Ryan EJ, Clark EA. 2003. Caspase activity is required for stimulated B lymphocytes to enter the cell cycle. J Immunol 170: 6065-6072.

Olsson M, Vakifahmetoglu H, Abruzzo PM, Hogstrand K, Grandien A, Zhivotovsky B. 2009. DISC-mediated activation of caspase-2 in DNA damage-induced apoptosis. Oncogene 28: 1949-1959.

Onouchi Y, Ozaki K, Buns JC, Shimizu C, Hamada H, Honda T, Terai M, Honda A, Takeuchi T, Shibuta S, et al. 2010. Common variants in CASP3 confer susceptibility to Kawasaki disease. Hum Mol Genet 19: $2898-$ 2906.

O’Reilly LA, Ekert P, Harvey N, Marsden V, Cullen L, Vaux DL, Hacker G, Magnusson C, Pakusch M, Cecconi F, et al. 2002. Caspase-2 is not required for thymocyte or neuronal apoptosis even though cleavage of caspase- 2 is dependent on both Apaf-1 and caspase-9. Cell Death Differ 9: 832-841.

Osorio F, Reis ESC. 2011. Myeloid C-type lectin receptors in pathogen recognition and host defense. Immunity 34: 651-664.

Papin S, Cuenin S, Agostini L, Martinon F, Werner S, Beer HD, Grutter C, Grutter M, Tschopp J. 2007. The SPRY domain of Pyrin, mutated in familial Mediterranean fever patients, interacts with inflammasome components and inhibits proIL-1 $\beta$ processing. Cell Death Differ 14: 1457-1466.

Park HH, Wu H. 2006. Crystal structure of RAIDD death domain implicates potential mechanism of PIDDosome assembly. J Mol Biol 357: 358-364.

Park WS, Lee JH, Shin MS, Park JY, Kim HS, Kim YS, Lee SN, Xiao W, Park CH, Lee SH, et al. 2002. Inactivating mutations of the caspase-10 gene in gastric cancer. Oncogene 21: 2919-2925.
Park SJ, Wu CH, Gordon JD, Zhong X, Emami A, Safa AR. 2004. Taxol induces caspase-10-dependent apoptosis. $J$ Biol Chem 279: 51057-51067.

Park JY, Park JM, Jang JS, Choi JE, Kim KM, Cha SI, Kim CH, Kang YM, Lee WK, Kam S, et al. 2006. Caspase 9 promoter polymorphisms and risk of primary lung cancer. Hum Mol Genet 15: 1963-1971.

Park HH, Logette E, Raunser S, Cuenin S, Walz T, Tschopp J, Wu H. 2007. Death domain assembly mechanism revealed by crystal structure of the oligomeric PIDDosome core complex. Cell 128: 533-546.

Pascual V, Allantaz F, Arce E, Punaro M, Banchereau J. 2005. Role of interleukin-1 (IL-1) in the pathogenesis of systemic onset juvenile idiopathic arthritis and clinical response to IL-1 blockade. J Exp Med 201: 1479-1486.

Peterson QP, Hsu DC, Goode DR, Novotny CJ, Totten RK, Hergenrother PJ. 2009. Procaspase-3 activation as an anti-cancer strategy: Structure-activity relationship of procaspase-activating compound 1 (PAC-1) and its cellular co-localization with caspase-3. J Med Chem 52: 5721-5731.

Peterson QP, Hsu DC, Novotny CJ, West DC, Kim D, Schmit JM, Dirikolu L, Hergenrother PJ, Fan TM. 2010. Discovery and canine preclinical assessment of a nontoxic procaspase-3-activating compound. Cancer Res 70: $7232-7241$.

Philchenkov A, Zavelevich M, Kroczak TJ, Los M. 2004. Caspases and cancer: Mechanisms of inactivation and new treatment modalities. Exp Oncol 26: 82-97.

Poyet JL, Srinivasula SM, Tnani M, Razmara M, FernandesAlnemri T, Alnemri ES. 2001. Identification of Ipaf, a human caspase-1-activating protein related to Apaf-1. J Biol Chem 276: 28309-28313.

Putt KS, Chen GW, Pearson JM, Sandhorst JS, Hoagland MS, Kwon JT, Hwang SK, Jin H, Churchwell MI, Cho MH, et al. 2006. Small-molecule activation of procaspase- 3 to caspase- 3 as a personalized anticancer strategy. Nat Chem Biol 2: 543-550.

Rathinam VA, Jiang Z, Waggoner SN, Sharma S, Cole LE, Waggoner L, Vanaja SK, Monks BG, Ganesan S, Latz E, et al. 2010. The AIM2 inflammasome is essential for host defense against cytosolic bacteria and DNA viruses. Nat Immunol 11: 395-402.

Renolleau S, Fau S, Goyenvalle C, Joly LM, Chauvier D, Jacotot E, Mariani J, Charriaut-Marlangue C. 2007. Specific caspase inhibitor Q-VD-OPh prevents neonatal stroke in P7 rat: A role for gender. J Neurochem 100: 1062-1071.

Riedl SJ, Shi Y. 2004. Molecular mechanisms of caspase regulation during apoptosis. Nat Rev Mol Cell Biol 5: 897-907.

Rohn TT, Head E. 2009. Caspases as therapeutic targets in Alzheimer's disease: Is it time to "cut" to the chase? Int $J$ Clin Exp Pathol 2: 108-118.

Rohn TT, Head E, Su JH, Anderson AJ, Bahr BA, Cotman CW, Cribbs DH. 2001. Correlation between caspase activation and neurofibrillary tangle formation in Alzheimer's disease. Am J Pathol 158: 189-198.

Roldan R, Ruiz AM, Miranda MD, Collantes E. 2008. Anakinra: New therapeutic approach in children with $\mathrm{Fa}$ milial Mediterranean Fever resistant to colchicine. Joint Bone Spine 75: 504-505. 
D.R. Mcllwain et al.

Roy S, Bayly CI, Gareau Y, Houtzager VM, Kargman S, Keen SL, Rowland K, Seiden IM, Thornberry NA, Nicholson DW. 2001. Maintenance of caspase-3 proenzyme dormancy by an intrinsic "safety catch" regulatory tripeptide. Proc Natl Acad Sci 98: 6132-6137.

Saleh M, Vaillancourt JP, Graham RK, Huyck M, Srinivasula SM, Alnemri ES, Steinberg MH, Nolan V, Baldwin CT, Hotchkiss RS, et al. 2004. Differential modulation of endotoxin responsiveness by human caspase12 polymorphisms. Nature 429: 75-79.

Saleh M, Mathison JC, Wolinski MK, Bensinger SJ, Fitzgerald P, Droin N, Ulevitch RJ, Green DR, Nicholson DW. 2006. Enhanced bacterial clearance and sepsis resistance in caspase-12-deficient mice. Nature 440: 1064-1068.

Salmena L, Lemmers B, Hakem A, Matysiak-Zablocki E, Murakami K, Au PY, Berry DM, Tamblyn L, Shehabeldin A, Migon E, et al. 2003. Essential role for caspase 8 in T-cell homeostasis and T-cell-mediated immunity. Genes Dev 17: 883-895.

Samraj AK, Keil E, Ueffing N, Schulze-Osthoff K, Schmitz I. 2006. Loss of caspase- 9 provides genetic evidence for the type I/II concept of CD95-mediated apoptosis. J Biol Chem 281: 29652-29659.

Schroder K, Tschopp J. 2010. The inflammasomes. Cell 140: 821-832.

Scott AM, Saleh M. 2007. The inflammatory caspases: Guardians against infections and sepsis. Cell Death Differ 14: $23-31$.

Seshadri S, Duncan MD, Hart JM, Gavrilin MA, Wewers MD. 2007. Pyrin levels in human monocytes and monocyte-derived macrophages regulate IL- $1 \beta$ processing and release. J Immunol 179: 1274-1281.

Shi L, Chen G, MacDonald G, Bergeron L, Li H, Miura M, Rotello RJ, Miller DK, Li P, Seshadri T, et al. 1996. Activation of an interleukin 1 converting enzyme-dependent apoptosis pathway by granzyme B. Proc Natl Acad Sci 93: 11002-11007.

Shi M, Vivian CJ, Lee KJ, Ge C, Morotomi-Yano K, Manzl C, Bock F, Sato S, Tomomori-Sato C, Zhu R, et al. 2009. DNA-PKcs-PIDDosome: A nuclear caspase-2-activating complex with role in $\mathrm{G} 2 / \mathrm{M}$ checkpoint maintenance. Cell 136: 508-520.

Shin MS, Kim HS, Kang CS, Park WS, Kim SY, Lee SN, Lee JH, Park JY, Jang JJ, Kim CW, et al. 2002. Inactivating mutations of CASP10 gene in non-Hodgkin lymphomas. Blood 99: 4094-4099.

Shiozaki EN, Chai J, Shi Y. 2002. Oligomerization and activation of caspase-9, induced by Apaf-1 CARD. Proc Natl Acad Sci 99: 4197-4202.

Shoham NG, Centola M, Mansfield E, Hull KM, Wood G, Wise CA, Kastner DL. 2003. Pyrin binds the PSTPIP1/ $\mathrm{CD} 2 \mathrm{BP} 1$ protein, defining familial Mediterranean fever and PAPA syndrome as disorders in the same pathway. Proc Natl Acad Sci 100: 13501-13506.

Sidi S, Sanda T, Kennedy RD, Hagen AT, Jette CA, Hoffmans R, Pascual J, Imamura S, Kishi S, Amatruda JF et al. 2008. Chk1 suppresses a caspase-2 apoptotic response to DNA damage that bypasses $\mathrm{p} 53, \mathrm{Bcl}-2$, and caspase-3. Cell 133: 864-877.

So A, De Smedt T, Revaz S, Tschopp J. 2007. A pilot study of IL-1 inhibition by anakinra in acute gout. Arthritis Res Ther 9: R28.
Soung YH, Lee JW, Kim HS, Park WS, Kim SY, Lee JH, Park JY, Cho YG, Kim CJ, Park YG, et al. 2003. Inactivating mutations of CASPASE-7 gene in human cancers. Oncogene 22: 8048-8052.

Soung YH, Lee JW, Kim SY, Park WS, Nam SW, Lee JY, Yoo NJ, Lee SH. 2004. Somatic mutations of CASP3 gene in human cancers. Hum Genet 115: 112-115.

Soung YH, Lee JW, Kim SY, Jang J, Park YG, Park WS, Nam SW, Lee JY, Yoo NJ, Lee SH. 2005a. CASPASE-8 gene is inactivated by somatic mutations in gastric carcinomas. Cancer Res 65: 815-821.

Soung YH, Lee JW, Kim SY, Sung YJ, Park WS, Nam SW, Kim SH, Lee JY, Yoo NJ, Lee SH. 2005b. Caspase-8 gene is frequently inactivated by the frameshift somatic mutation 1225_1226delTG in hepatocellular carcinomas. Oncogene 24: 141-147.

Soung YH, Jeong EG, Ahn CH, Kim SS, Song SY, Yoo NJ, Lee SH. 2008. Mutational analysis of caspase 1, 4, and 5 genes in common human cancers. Hum Pathol 39: 895-900.

Spencer SL, Gaudet S, Albeck JG, Burke JM, Sorger PK. 2009. Non-genetic origins of cell-to-cell variability in TRAIL-induced apoptosis. Nature 459: 428-432.

Spranger J, Kroke A, Mohlig M, Hoffmann K, Bergmann MM, Ristow M, Boeing H, Pfeiffer AF. 2003. Inflammatory cytokines and the risk to develop type 2 diabetes: Results of the prospective population-based European Prospective Investigation into Cancer and Nutrition (EPIC)-Potsdam Study. Diabetes 52: 812-817.

Sprick MR, Rieser E, Stahl H, Grosse-Wilde A, Weigand MA, Walczak H. 2002. Caspase- 10 is recruited to and activated at the native TRAIL and CD95 death-inducing signalling complexes in a FADD-dependent manner but can not functionally substitute caspase-8. EMBO J 21: 45204530.

Stack JH, Beaumont K, Larsen PD, Straley KS, Henkel GW, Randle JC, Hoffman HM. 2005. IL-converting enzyme/ caspase-1 inhibitor VX-765 blocks the hypersensitive response to an inflammatory stimulus in monocytes from familial cold autoinflammatory syndrome patients. J Immunol 175: 2630-2634.

Steimle V, Otten LA, Zufferey M, Mach B. 1993. Complementation cloning of an MHC class II transactivator mutated in hereditary MHC class II deficiency (or bare lymphocyte syndrome). Cell 75: 135-146.

Straathof KC, Pule MA, Yotnda P, Dotti G, Vanin EF Brenner MK, Heslop HE, Spencer DM, Rooney CM. 2005. An inducible caspase 9 safety switch for T-cell therapy. Blood 105: 4247-4254.

Straus SE, Sneller M, Lenardo MJ, Puck JM, Strober W. 1999. An inherited disorder of lymphocyte apoptosis: The autoimmune lymphoproliferative syndrome. Ann Intern Med 130: 591-601.

Stupack DG, Teitz T, Potter MD, Mikolon D, Houghton PJ, Kidd VJ, Lahti JM, Cheresh DA. 2006. Potentiation of neuroblastoma metastasis by loss of caspase- 8 . Nature 439: 95-99.

Sutterwala FS, Ogura Y, Szczepanik M, Lara-Tejero M, Lichtenberger GS, Grant EP, Bertin J, Coyle AJ, Galan JE, Askenase PW, et al. 2006. Critical role for NALP3/ CIAS1/Cryopyrin in innate and adaptive immunity 
through its regulation of caspase-1. Immunity 24: 317327.

Sutterwala FS, Mijares LA, Li L, Ogura Y, Kazmierczak BI, Flavell RA. 2007. Immune recognition of Pseudomonas aeruginosa mediated by the IPAF/NLRC4 inflammasome. J Exp Med 204: 3235-3245.

Suzuki T, Franchi L, Toma C, Ashida H, Ogawa M, Yoshikawa Y, Mimuro H, Inohara N, Sasakawa C, Nunez G. 2007. Differential regulation of caspase- 1 activation, pyroptosis, and autophagy via Ipaf and ASC in Shigellainfected macrophages. PLoS Pathog 3: el11.

Taylor RC, Cullen SP, Martin SJ. 2008. Apoptosis: Controlled demolition at the cellular level. Nat Rev Mol Cell Biol 9: 231-241.

Teitz T, Wei T, Valentine MB, Vanin EF, Grenet J, Valentine VA, Behm FG, Look AT, Lahti JM, Kidd VJ. 2000. Caspase 8 is deleted or silenced preferentially in childhood neuroblastomas with amplification of MYCN. Nat Med 6: 529-535.

Terkeltaub R, Sundy JS, Schumacher HR, Murphy F, Bookbinder S, Biedermann S, Wu R, Mellis S, Radin A. 2009. The interleukin 1 inhibitor rilonacept in treatment of chronic gouty arthritis: Results of a placebo-controlled, monosequence crossover, non-randomised, single-blind pilot study. Ann Rheum Dis 68: 1613-1617.

Tey SK, Dotti G, Rooney CM, Heslop HE, Brenner MK. 2007. Inducible caspase 9 suicide gene to improve the safety of allodepleted $\mathrm{T}$ cells after haploidentical stem cell transplantation. Biol Blood Marrow Transplant 13: 913-924.

Thomas PG, Dash P, Aldridge JR Jr, Ellebedy AH, Reynolds C, Funk AJ, Martin WJ, Lamkanfi M, Webby RJ, Boyd KL, et al. 2009. The intracellular sensor NLRP3 mediates key innate and healing responses to influenza A virus via the regulation of caspase-1. Immunity 30: 566-575.

Tinel A, Tschopp J. 2004. The PIDDosome, a protein complex implicated in activation of caspase- 2 in response to genotoxic stress. Science 304: 843-846.

Ting JP, Lovering RC, Alnemri ES, Bertin J, Boss JM, Davis BK, Flavell RA, Girardin SE, Godzik A, Harton JA, et al. 2008a. The NLR gene family: A standard nomenclature. Immunity 28: 285-287.

Ting JP, Willingham SB, Bergstralh DT. 2008b. NLRs at the intersection of cell death and immunity. Nat Rev Immunol 8: $372-379$.

Tschopp J. 2011. Mitochondria: Sovereign of inflammation? Eur J Immunol 41: 1196-1202.

Tschopp J, Martinon F, Burns K. 2003. NALPs: A novel protein family involved in inflammation. Nat Rev Mol Cell Biol 4: 95-104.

Tu S, McStay GP, Boucher LM, Mak T, Beere HM, Green DR. 2006. In situ trapping of activated initiator caspases reveals a role for caspase- 2 in heat shock-induced apoptosis. Nat Cell Biol 8: 72-77.

van der Meer JW, Vossen JM, Radl J, van Nieuwkoop JA, Meyer CJ, Lobatto S, van Furth R. 1984. Hyperimmunoglobulinaemia D and periodic fever: A new syndrome. Lancet 1: 1087-1090.

Varfolomeev EE, Schuchmann M, Luria V, Chiannilkulchai N, Beckmann JS, Mett IL, Rebrikov D, Brodianski VM,
Kemper OC, Kollet O, et al. 1998. Targeted disruption of the mouse Caspase 8 gene ablates cell death induction by the TNF receptors, Fas/Apo1, and DR3 and is lethal prenatally. Immunity 9: 267-276.

Vogler M, Dinsdale D, Dyer MJ, Cohen GM. 2009. Bcl-2 inhibitors: Small molecules with a big impact on cancer therapy. Cell Death Differ 16: 360-367.

Wang L, Miura M, Bergeron L, Zhu H, Yuan J. 1994. Ich-1, an Ice/ced-3-related gene, encodes both positive and negative regulators of programmed cell death. Cell 78: 739-750.

Wang S, Miura M, Jung YK, Zhu H, Li E, Yuan J. 1998. Murine caspase-11, an ICE-interacting protease, is essential for the activation of ICE. Cell 92: 501-509.

Wang J, Zheng L, Lobito A, Chan FK, Dale J, Sneller M, Yao X, Puck JM, Straus SE, Lenardo MJ. 1999. Inherited human Caspase 10 mutations underlie defective lymphocyte and dendritic cell apoptosis in autoimmune lymphoproliferative syndrome type II. Cell 98: 47-58.

Watanabe H, Gaide O, Petrilli V, Martinon F, Contassot E, Roques S, Kummer JA, Tschopp J, French LE. 2007. Activation of the IL-1 $\beta$-processing inflammasome is in volved in contact hypersensitivity. I Invest Dermatol 127: 1956-1963.

Wewers MD, Herzyk DJ. 1989. Alveolar macrophages differ from blood monocytes in human IL- $1 \beta$ release. Quantitation by enzyme-linked immunoassay. J Immunol 143: 1635-1641.

Wise CA, Gillum JD, Seidman CE, Lindor NM, Veile R, Bashiardes S, Lovett M. 2002. Mutations in CD2BP1 disrupt binding to PTP PEST and are responsible for PAPA syndrome, an autoinflammatory disorder. Hum $\mathrm{Mol} \mathrm{Ge}$ net 11: 961-969.

Woo M, Hakem R, Soengas MS, Duncan GS, Shahinian A, Kagi D, Hakem A, McCurrach M, Khoo W, Kaufman SA, et al. 1998. Essential contribution of caspase 3/CPP32 to apoptosis and its associated nuclear changes. Genes Dev 12: $806-819$.

Woo M, Hakem R, Furlonger C, Hakem A, Duncan GS, Sasaki T, Bouchard D, Lu L, Wu GE, Paige CJ, et al 2003. Caspase- 3 regulates cell cycle in B cells: A consequence of substrate specificity. Nat Immunol 4: 10161022.

Xu HL, Xu WH, Cai Q, Feng M, Long J, Zheng W, Xiang YB, Shu XO. 2009. Polymorphisms and haplotypes in the caspase- 3 , caspase- 7 , and caspase- 8 genes and risk for endometrial cancer: A population-based, case-control study in a Chinese population. Cancer Epidemiol Biomarkers Prev 18: 2114-2122.

Xue Y, Daly A, Yngvadottir B, Liu M, Coop G, Kim Y, Sabeti P, Chen Y, Stalker J, Huckle E, et al. 2006. Spread of an inactive form of caspase-12 in humans is due to recent positive selection. Am J Hum Genet 78: 659-670.

Yamasaki K, Muto J, Taylor KR, Cogen AL, Audish D, Bertin J, Grant EP, Coyle AJ, Misaghi A, Hoffman HM et al. 2009. NLRP3/cryopyrin is necessary for interleukin-1 $\beta$ (IL-1 $\beta$ ) release in response to hyaluronan, an endogenous trigger of inflammation in response to injury. J Biol Chem 284: 12762-12771.

Yang GY, Schielke GP, Gong C, Mao Y, Ge HL, Liu XH, Betz AL. 1999. Expression of tumor necrosis factor- $\alpha$ and intercellular adhesion molecule- 1 after focal cerebral 
D.R. Mcllwain et al.

ischemia in interleukin- $1 \beta$ converting enzyme deficient mice. J Cereb Blood Flow Metab 19: 1109-1117.

Yang X, Merchant MS, Romero ME, Tsokos M, Wexler LH, Kontny U, Mackall CL, Thiele CJ. 2003. Induction of caspase 8 by interferon $\gamma$ renders some neuroblastoma (NB) cells sensitive to tumor necrosis factor-related apoptosis-inducing ligand (TRAIL) but reveals that a lack of membrane TR1/TR2 also contributes to TRAIL resistance in NB. Cancer Res 63: 1122-1129.

Yeh WC, Pompa JL, McCurrach ME, Shu HB, Elia AJ, Shahinian A, Ng M, Wakeham A, Khoo W, Mitchell K, et al. 1998. FADD: Essential for embryo development and signaling from some, but not all, inducers of apoptosis. Science 279: 1954-1958.

Yeh WC, Itie A, Elia AJ, Ng M, Shu HB, Wakeham A, Mirtsos C, Suzuki N, Bonnard M, Goeddel DV, et al. 2000. Requirement for Casper (c-FLIP) in regulation of death receptor-induced apoptosis and embryonic development. Immunity 12: 633-642.

Yin M, Yan J, Wei S, Wei Q. 2010. CASP8 polymorphisms contribute to cancer susceptibility: Evidence from a meta-analysis of 23 publications with 55 individual studies. Carcinogenesis 31: 850-857.

Ying Lu G-QC. 2011. Effector Caspases and Leukemia. Int J Cell Biol 2011. doi: 10.1155/2011/738301.

Yoo NJ, Lee JW, Kim YJ, Soung YH, Kim SY, Nam SW, Park WS, Lee JY, Lee SH. 2004. Loss of caspase-2, -6 and -7 expression in gastric cancers. APMIS 112: 330-335.
Yoshida H, Kong YY, Yoshida R, Elia AJ, Hakem A, Hakem R, Penninger JM, Mak TW. 1998. Apaf1 is required for mitochondrial pathways of apoptosis and brain development. Cell 94: 739-750.

Yu JW, Wu J, Zhang Z, Datta P, Ibrahimi I, Taniguchi S, Sagara J, Fernandes-Alnemri T, Alnemri ES. 2006. Cryopyrin and pyrin activate caspase-1, but not NF- $\mathrm{kB}$, via ASC oligomerization. Cell Death Differ 13: 236-249.

Zhang J, Cado D, Chen A, Kabra NH, Winoto A. 1998. Fasmediated apoptosis and activation-induced T-cell proliferation are defective in mice lacking FADD/Mort1. $\mathrm{Na}$ ture 392: 296-300.

Zhang WH, Wang X, Narayanan M, Zhang Y, Huo C, Reed JC, Friedlander RM. 2003. Fundamental role of the Rip2/caspase-1 pathway in hypoxia and ischemiainduced neuronal cell death. Proc Natl Acad Sci 100: 16012-16017.

Zhang HZ, Kasibhatla S, Wang Y, Herich J, Guastella J, Tseng B, Drewe J, Cai SX. 2004. Discovery, characterization and SAR of gambogic acid as a potent apoptosis inducer by a HTS assay. Bioorg Med Chem 12: 309-317.

Zhang H, Zhou X, McQuade T, Li J, Chan FK, Zhang J. 2011. Functional complementation between FADD and RIP1 in embryos and lymphocytes. Nature 471: 373-376.

Zheng TS, Hunot S, Kuida K, Flavell RA. 1999. Caspase knockouts: Matters of life and death. Cell Death Differ 6: $1043-1053$. 


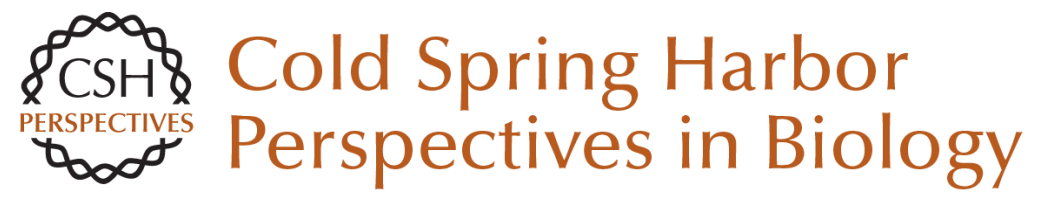

\section{Caspase Functions in Cell Death and Disease}

David R. Mcllwain, Thorsten Berger and Tak W. Mak

Cold Spring Harb Perspect Biol 2013; doi: 10.1101/cshperspect.a008656

Subject Collection Cell Survival and Cell Death

Programmed Cell Death in the Evolutionary Race against Bacterial Virulence Factors

Carolyn A. Lacey and Edward A. Miao

The Evolutionary Origins of Programmed Cell

Death Signaling

Kay Hofmann

Regulation of Cell Death and Immunity by XIAP Philipp J. Jost and Domagoj Vucic

Dysregulation of Cell Death in Human Chronic Inflammation

Yue Li, Christoph Klein and Daniel Kotlarz

Cell Death in Plant Immunity

Eugenia Pitsili, Ujjal J. Phukan and Nuria S. Coll

Recent Insights on Inflammasomes, Gasdermin Pores, and Pyroptosis

Nathalia M. de Vasconcelos and Mohamed Lamkanfi

Phagocyte Responses to Cell Death in Flies Andrew J. Davidson and Will Wood

Mechanism and Regulation of

Gasdermin-Mediated Cell Death

Shiyu Xia, Louis Robert Hollingsworth IV and Hao Wu
Cell Death and Neurodegeneration Benjamin J. Andreone, Martin Larhammar and Joseph W. Lewcock

Death Receptors and Their Ligands in Inflammatory Disease and Cancer Alessandro Annibaldi and Henning Walczak

The Killer Pseudokinase Mixed Lineage Kinase Domain-Like Protein (MLKL) James M. Murphy

Neutrophil Extracellular Traps in Host Defense Sabrina Sofia Burgener and Kate Schroder

Cell-Cycle Cross Talk with Caspases and Their Substrates Patrick Connolly, Irmina Garcia-Carpio and Andreas Villunger

Cracking the Cell Death Code Carla V. Rothlin and Sourav Ghosh

BAX, BAK, and BOK: A Coming of Age for the BCL-2 Family Effector Proteins

Tudor Moldoveanu and Peter E. Czabotar

Multitasking Kinase RIPK1 Regulates Cell Death and Inflammation

Kim Newton

For additional articles in this collection, see http://cshperspectives.cshlp.org/cgi/collection/

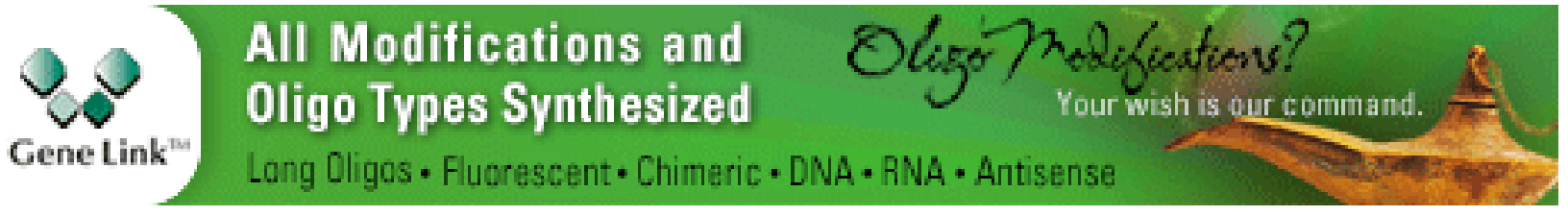

Copyright @ 2013 Cold Spring Harbor Laboratory Press; all rights reserved 
For additional articles in this collection, see http://cshperspectives.cshlp.org/cgi/collection/

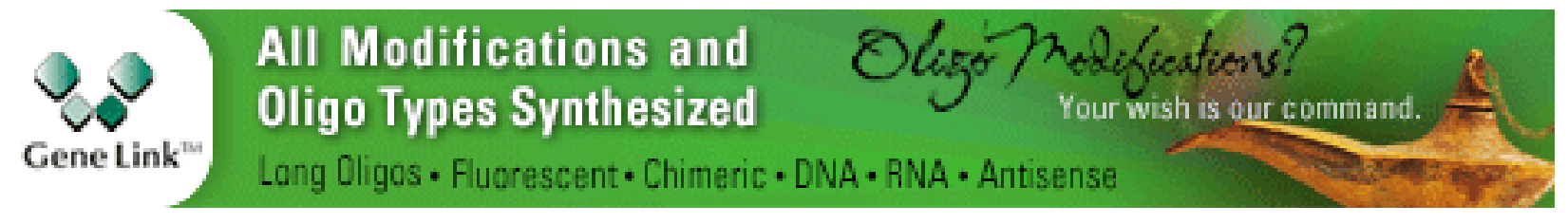

Copyright @ 2013 Cold Spring Harbor Laboratory Press; all rights reserved 